\title{
فاعلية التدريب المتقطع عالي الكثافة (HIIT) على تطوير الحالة التدريبية البدنية والمهارية والفسيولوجية للمصارعين
}

أ.م.د "بلال مرسى محمد وتوت

قام الباحث بدراسة بعنوان" فاعلية التدريب المتقطع عالي الكثافة (HIIT) على تطوير الحالة التدريبية البدنية والمهارية والفسيولوجية للمصارعين" بهدف تصميم برنامج تدريبي باستخدام أسلوب التدريب المتقطع عالي الكثافة (HIIT) والتعرف على مدى تأثير البرنامج التدريبى على - - الحالة التدريبية البدنية والمهارية والفسيولوجية لدى أفراد المجموعة التجربيية

واستخدم الباحث المنهج التجريبي باستخدام التصميم التجريبي ذو القياس القبلي و البعدى على مجموعتين تجريبية وضابطة وتم اختيار عينة البحث بالطربقة العدية من لاعبي منتخب منطقة المنوفية (المرحلة المفتوحة) والبالغ عددهم ( • ( ) لاعب بواقع (• () لاعبين لكل مجموعة وأسفرت النتائج إلى ا- البرنامج التدربيى المقترح باستخدام أسلوب التدريب المتقطع عالى الكثافة (Hiit) أثز إيجابيا على تتمية الحالة البدنية قيد البحث لدى المجموعة التجريبية. ץ- البرنامج التدربيى المقترح باستخدام أسلوب التدريب المتقطع عالى الكثافة (Hiit) أثز إيجابيا على تتمية الحالة المهارية قيد البحث لدى المجموعة التجريبية. r- البرنامج التدربيى المقتزح باستخدام أسلوب التدربب المتقطع عالى الكثافة (Hiit) أثز إيجابيا على تتمية الحالة الفسيولوجية قيد البحث لدى المجموعة التجريبية. الكلمات الرئيسية المصارعة ، لتدريب؛ المتقطع؛ عالي؛ الكثافة 


\section{المقدمة ومشكلة البحث}

لقد أصبح التقدم العلمي السمة المميزة للعصر الحالي لما يساهم في إيجاد الكثير من الحلول العلمية للعديد من المشكلات في جميع مجالات الحياة بصفة عامة ومجال التربية البدينة والرياضـة بصفة خاصـة، وعليه فقد تقدمت أسـاليب التدريب مستقبدة مسن ذلك بمبدأ التكامل بين العلوم والمعـارف المختلفة والتي تهدف إلى الوصول باللاعب إلى المستوى الذي يمكنه من تحقيق أفضل الانجازات الرياضية في المواقف التنافسية في مجال تخصصه وفى حدود ما تسمح به قدراته الفنية. حيث يرى نبيل الثوربجى (^ . . r) أن المتابع للبطولات الرياضية خاصة فى مجال رياضات النزال سوف يلاحظ مدى التطور الذى تشهده الألفية الثالثة فى مجال تدريب رياضـات المنازلات على وجها العموم ورياضـة المصسارعة على وجـه الخصوص حيث شهـت السنوات الأخيرة انفجارا علميا فى

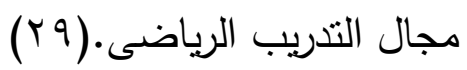

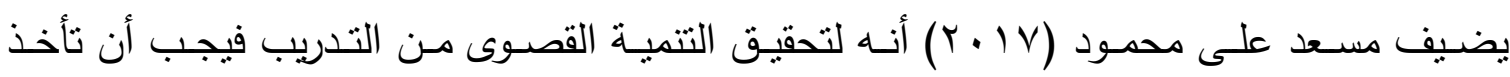
التمرينات شكل وطبيعة الأداء المهارى لنوع النشاط الممارس من حيث زمن الأداء، وطبيعة الأداء ، وتعاقـب فتـرات العمـل والراحـة، والعضــلات العاملـة، والمســارات الحركيـة، والعنصــر المـراد (s): تتميته. يشير محمد رضا الروبى (0 . . r) أنه يجب الربط بين زمن الأداء، وشكل الأداء والطاقة المطلوبـة لإنجازه، والقوة والسرعة التى يتم بها الأداء، واستخدام العضـلات بالقدرة والتوقيت المناسب، ودراسـة المتطلبات المتعددة البدنية والمهارية والفسيولوجية لفاعلية الحركة.(ع ب: (ب0) ويذكر كل من محمد حسن عـلاوي، أبو العـلا عبد الفتاح ( ... . أن أن المدرب الناجح هو الذي يخطط برنامجه التدريبي بحيث ينمي هذا البرنامج الخصائص التي يتطلبها نوع النشاط التخصصي للاعب ويشمل ذلك تدريب اللاعب باستخدام التدربيات التي تعمل علي تتميـة نظام الطاقـة الذي يعتمد عليـة اللاعب في تخصصسه الرياضـي كما يجب أن تسـتخدم نفس الحركات الخاصـة بهذا النشـاط حتى يـتم التركيز علي تدريب المجموعـات العضـلية العاملـة والمشـتركة في أداء النشـاط الرياضي التخصصي تبعا لطبيعة عملها .(TV : (TV 
ويشـير إيهاب البديوى (ع . . r) إلى أن أسـاليب ووسـائل التدريب المختلفـة مـا هـ إلى تدريبات تطبيقية موجهه لتحقيق هدف العملية التدربيية، فيجب على المدرب معرفة هذه الوسائل والأساليب المختلفة والحديث منها واختيار ما هو مناسب ومالأم لتحقيق أفضل مستوى أداء ممكن.(V) ويذكر مسـعد على محمـود (ب . . r) أن التـدريب يتعلق فـى المقـام الأول بتتميـة القدرات الخاصـة بالأداء المهارى للمنافسات، ويهدف برنامج التدريب إلى تحسين القدرات الوظيفية للجسم بالإضـافة لتتميـة الأداء الفنى والخططى ويعطى برنـامج التدريب اعتبـارا متسـاويا لكل مـن القدرات البدنيـة والمهارية والوظيفية، أى يهتم بالإعداد الثامل والمتتوع الذى يهتم بالتفاصيل الأخرى للبرنامج كالراحة واستعادة الشفاء.(Y) ورياضـة المصارعة من الرياضات التي يقع فيها اللاعب تحت حمل عالي في المباراة حيث تكون شدة الأداء عالية ويصاحب ذلك مجهود كبير على أجهزة الجسم واستمرار هذا المجهود خلال زمن المباراة يؤدى إلي تعرض اللاعب للتعب والإجهاد وعدم القدرة على مواصلة الأداء بنفس قوة بدايـة المباراة ، ويرجع ذلك إلى هبوط إمكانيات اللاعب البدنية والمهارية والخططية أو لنقص الأكسجين

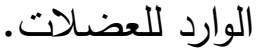
ويذكر محمد فتحى نصار (0 ( . ب) إن رياضة المصارعة من الأنشطة التي تتطلب مستوي عال من الكفاءة البدنية والفسيولوجية حتى يتمكن اللاعب من أداء واجباته المهاربـة والخططية المكلف بها

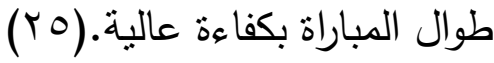
حيث يضيف أيهاب صبرى، نبيل الثوربجى (r r) أن المصارعة من الرياضات التى تتطلب بذل مجهود بـنى شـاق أثتـاء التـدريب أوالمباريـات وهذا يتطلب قدرات بدنيـة ووظيفيـة خاصـة للاعبى (7). (7) (1) (1) ويشير على السعيد ريحان (r . . r) من خلال تحليل المباريات وجد أن المباريات المحلية والدولية معظمها تتتهى بانتهاء زمن المباراة، فيقع على عاتق اللاعب عبء كبير لمجابهة متطلبات أداء

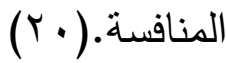
ففى مباراة المصارعة تتكون من جولتين زمن كل جولة ساق بينهما · ست راحة، الاداء خلال المباراة ليس ثابت من حيث طبيعة وسرعة وقوة الأداء ولكن يتغير رتم وكثافة الأداء داخل المبارة وفقا لعدة 
متغيرات منها، طريقة الصراع مع المنافس من حيث صراع مفتوح من حيث تبادل الالتحام ومحاولة الهجوم والدفاع، وصـراع مغلق ذو طبيعـة أداء بطيئة وعدم البدء فى الصـراع والهجوم والانتظـار لتصيد الاخطاء والنقاط، فمن التحليل العام للمباراة نجد انها تتاوب بين الحركة والسكون، تغير فى رتم الأداء بين الصراع الايجابى السربع ذو قوة وفاعلية وبين البطء والتظاهر بالصراع. حيث يضيف بى فاسكونكلوز وأخرون B. Vasconcelos \& others ( • • • (Y) على آثار التدريب الفاصـل عـالي الكثافة في رباضـات النزال حيث أن رياضـات المنـازلات متقطعـة بطبيعتها فيفضل استخدام التدريب المتقطع عـالي الكثافة (HIIT) كأداة للحفاظ على اللياقة البدنيـة وتحسينها بين رياضات فنون الدفاع عن النفس، الجودو، التايكوندو، الجيو جيتسو، الملاكمة، الكاراتيه، المصارعة، الوشـو كونج فو، فسوف تعمل على تحسن فى القدرات الهوائية، ومعدل ضـربات القلب، والحد الأقصىى لاستهلاك الأكسجين، القدرة اللاهوائية القصوى والمتوسطة، وتركيز حمض اللاكتلك في الدم، ونسبة الدهون في الجسم، والتأثير على كتلة الجسم ونسبة الدهون في الجسم.(سب) ويذكر حسين فهـى عبد الظـاهر (1999 () من خـلال دراسـة تحليليـة لمباريات المصـارعة وجد أن اللاعب يقوم بعدة مسكات ومهارات خلا المباراة قد تصل إلى 10 مسكة بقوه عالية ومثلها حركات دفاع بشـده عاليـة ضـد مسكات المصـارع المهاجم وهذا يتطلب مستوى عـالي من الأداء العضـلي

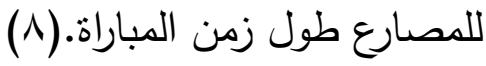
إن انخفاض مستوي الأداء الخـاص بالمصـارعين يؤدي إلي ضـف المقدرة على مواصلة الصـراع بكفاءة عالية، وعدم إتمام الواجبات الخططية بنجاح خلال المباريات، إضـافة إلى التأثير سلبا علي سرعة الاستشفاء بين المباريات، أن مباراة المصارعة تتطلب المقدرة علي الاستمرار في بذل القوة بالحد الذي يكفل تتفيذ المهارات والتغلب علي مقاومة المنافس خلا زمن المباراة. ويشير عثمان حسين رفعت (r . . r) أنه لكى يقتضي الاستمرار في الصراع بكفاءة والمقدرة علي تتفيذ المهارات الهجومية مع الاحتفاظ بكفاءة وظيفية مرتفعة حتى نهاية المباراة، الأمر الذي يجعل اختيار طربقة التذربب المناسبة إحدى أهم الخطوات للوصول إلى أفضل مستوى أداء. (7 (: 1 (1) 
ولقد ظهرت العديد من أساليب ونظريات التدريب التي يستطيع منها المدرب أن يخلق برنامج تدريبي فعال يمكنه من تحسين الأداء ورفع كفاءة الإمكانات البدنية والمهارية والفسيولوجية للاعبين في كثير من الأنشطة الرياضية والتي تعتمد علي أقصي أداء في أقل زمن ممكن.

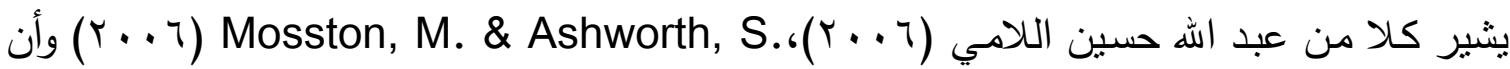
المبدأ الأساسي الذي يحدد عملية التدريب بطريقة التدريب المتقطع عالي الكثافة هو أوقات الراحة بـين تمـرين و آخـر أو بـين تكـرارات كـل تمـرين، فـالتمرين المكثن تقـل فيـه أو تتعـدم فتـرات

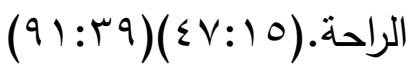

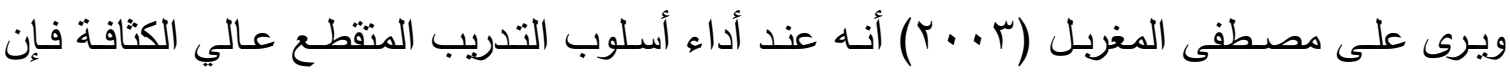
الوظيفة الرئيسية هى توزيع أوقات الراحة بين كل تدريب وآخر وبين تكرارات كل تدربب وتدريب أخر ، فيجب أن تكون الممارسة وتحديد مقدار الراحة أثثاء بناء التدربب من أهم اهتمامات المدرب وذلك أثناء وضـع التدريبات وتتظيمها خلال الوحدات فالتدريب المكثف يعطى نسبة راحة قليلة نسبياً بين محاولات التربب.(19:19)

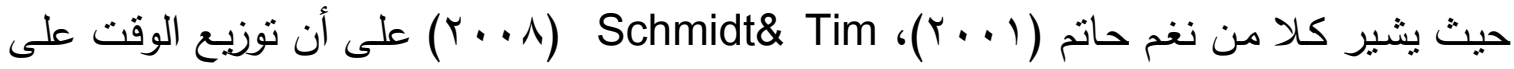
ممارسـة التدريبات تعد مـن العوامـل المهمـة والأساسـية التي تسـاعد على الارتفـاع بمسـتوى الأداء باستخدام التدريب المتقطع عالي الكثافة الذي يؤديه المتحلم باستمرار وثبات مع فترة قصيرة للراحة لأداء المهارة المطلوبة، وهذا يعنى أن اللاعب يؤدى التدريب في وقت محدد وبزيادة عدد محاولات

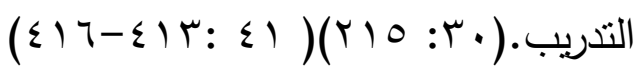

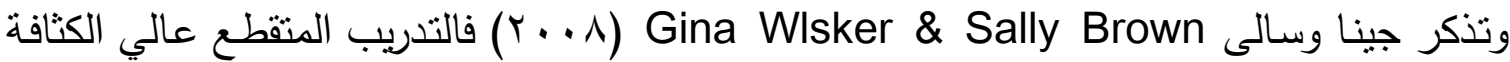
سلسـلة متعاقبـة مـن التدريب والراحـة والتي يجب أن تكـون فيهـا نسبة وقت الراحـة أقل مـن وقت

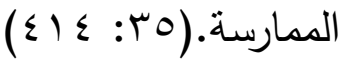

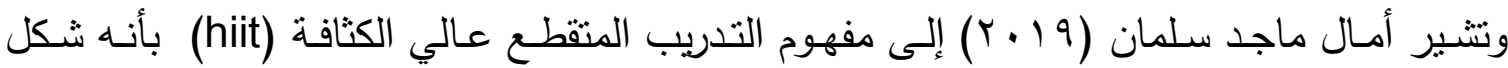
محسن من أثكال التدريب المتواتر أو المتقطع، كمـا أنها تعد إسـتراتيجية تمـارين بفترات متتاوبـة قصيرة تتميز بالكثافة مما يجعل الجسم بحاجة إلى كمية أوكسجين أكبر من المعتاد تتبعها فترات

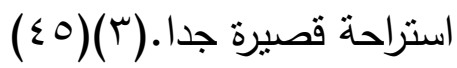


فالتدريب المتقطع عالي الكثافة (الهيت HIIT) هذا المصطلح اختصار لجملة high-intensity) (HIIT) يقدم هذا التدريب تمرين عالي الكثافة في فترة قصيرة، تعتبر تمارين (HIterval training) ذات شـعبية واسـعة فـي عـالم اللياقـة البدنيـة بفضــل الكفــاءة التـي تقـدمها فـي هـــا المجــال، فتمارين يعتبر مصطلح جامع لمجموعة منتوعة من التدريبات التي تشمل فترات قصيرة من الحركة القوية والجهد العالي تليها فترات راحة قصيرة منتظمة، وتكمن الفكرة في أن تدفع نفسك لتقديم أقصى جهد لديك مع أقصى أداء يمكن أن تقدمه في هذا التصرين في فترة قصيرة، تستمر مدة تمارين لمدة قصيرة غالباً وعلى الرغم من قصر هذه الفترة الزمنية الا أنها تقدم نتائج ايجابية وفعالية

عالية. (

أن التدريب المتقطع عـالي الكثافة هي طربقة تمرين وليست تمـارين معينة، فيها تكون التدربيات VO2 متقطعة عالية الثدة فهى تجعل الجسم يعمل بأقصى قوة في توصيل الأكسجين لعضـلاتكا والذي يمدك بالمزيد من الطاقة ويساعدك علي الأداء الجيد للتمارين وهذه واحدة من من أهم فوائد HIIT، وبالتالي زيادة القوة والتحمل، وسرعة الاستشفاء، ان ممارسـة تمارين HIIT لمدة عشر دقائق يحرق نفس كمية الدهون التي تحرق خلال ممارسـة ــ دقيقة من التمـارين العاديـة، وتعمل على تحسين معدل ضـربات القلب وضـبط ضـغط الدم فهذه الطريقـة تقيد أكثر الرياضـيين ذوى

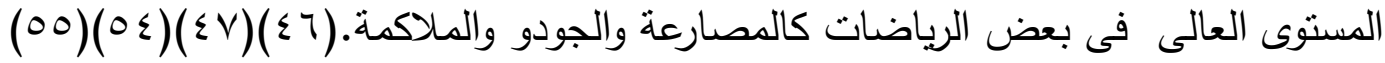
وتكمن أهمية اسلوب التدريب المتقطع عالي الكثافة (هيت Hiit Training) فى فقدان الدهون في الجسم (مسع الحفاظ على الكتلة العضلية)، كفاءة الدورة الدموية، تطوير أنظمـة طاقـة خاصـة بنوع النشاط الممارس، تطوير القدرة على تحمل درجة عالية من الثدة لفترة أطول، تحسين الدهون وأكسدة

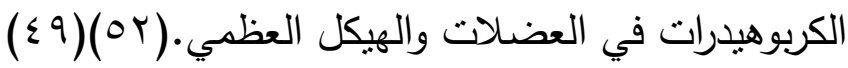
فتتبلور مشكلة البحث فى أنه من خلال ممارسة وخبرة الباحث برياضـة المصارعة لاحظ عدم قدرة اللاعبين على مواصلة الصراع بكفاءة عالية واختالا مستوى الأداء الفنى والبدنى والخططى وعدم القدرة على التغلب على مقاومة المنافس وظهور علامات التعب والاجهاد وهبوط امكانيات اللاعب وعدم القدرة على مواصلة الأداء بنفس قوة بداية المباراة، ويرى الباحث أنه قد برجع ذلك إلى عدة عوامل من أهمها قصور في طرق وأسـاليب التدريب المستخدمة وعدم تماتلها وتوافقها مـع أسلوب 
ونظـام المنافسـة مـن حيث سـرعة وقوة الأداء، زمـن الأداء، توزيـع الزمن بين العمل والراحـة داخل التكرارات والمجموعات مما يؤثز على نتائج المباريات مما سبق ظهرت الحاجة الملحة إلى وضع برنامج تدريبى على أسس علمية باستخدام طرق واستراتيجيات تدريب تتمانل مع ظروف المنافسة. وقد تم استخدام التدريب المتقع عالي الكثافة (HIIT)، والذى يعتمد على التتاوب بين الأداء والراحة بشرط ان يكون الأداء بالثدة القصوى في الزمن المحدد والراحة تتدرج حتى تصل إلى زمن أقل من زمـن الأداء فالتتـاوب بين الأداء بالثـدة القصـوى والراحـة الغير كاملـة خـلال المجموعـة تثماثل مـع ظروف المباراة وما يحدث بها.

ومن هذا المنطلق السابق تبلورت فكرة البحث في تصميم برنامج تدريبي باستخدام التدريب المتقطع عـالي الكثافـة (HIIT)، والتعـرف على مـدى فاعليتهـه على الحالـة التدريبيـة البدنيـة والمهاريـة والفسيولوجية للمصسارعين في محاولـة مـن الباحث تحسين الناحيـة البدنيـة والمهاريـة والفسيولوجية للمصارعين لكي يتكيفوا على متطلبات أداء المنافسة. *أهداف البحث: تصميم برنامج تدريبي باستخدام أسلوب التدريب المتقطع عالى الكثافة (HIIT) بهدف :ا - التعـرف على مـدى تـأثير البرنـامج التـدريبى علىى الحالـة التدريبيـة البدنبـة والمهاريـة والفسيولوجية لدى أفراد المجموعة التجريبية.

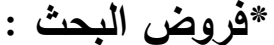

ا-توجد فروق ذات دلالـة إحصـائية بين القياس القبلي والقياس البعدى لكل مـن المجموعـة التجريبية والمجموعة الضـابطة في الحالة التدريبية البدنية والمهارية والفسيولوجية فى اتجاه

$$
\text { القياس البعدي. }
$$

r- توجد فروق ذات دلالة إحصائية بين القياسين البعديين للمجموعتين التجربيية والضابطة في الحالة التدربيية البدنية والمهارية والفسيولوجية لصالح المجموعة التجربيية.

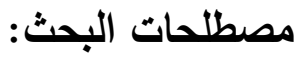
(التدريب المتقطع عالي الكثافة (الهيت High-intensity interval training)(HIT) 
هو اسـتراتيجية تمـارين بفترات متتاوبـة قصيرة تتميز بالكثافة ممـا يجعل الجسم بحاجـة إلى كميـة أوكسجين اكبر من المعتاد تتبعها فترات استراحة قصبرة جدا أقل من وقت الممارسـة ، فهو أسلوب مستحدث لرفع الكفاءة البدنية عن طريق أداء مجموعة من التدربيات البدنية أو المهارية في أقل وقت

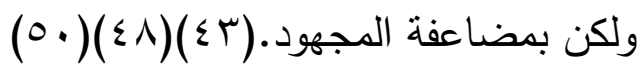
الاراسات السابقة

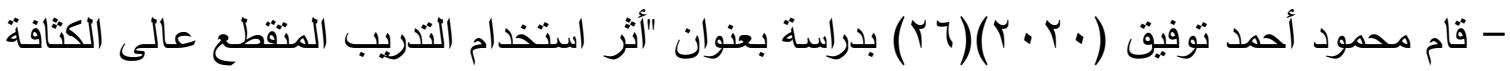
على تحسين مستوى اللياقـة البدنيـة وإنقاص الوزن للمصسارعين" بهدف التعرف على تأثير (Hiit) برنـامج التدريب المتقطع عـالى الكثافـة (Hiit) على تحسين مستوى اللياقـة البدنيـة وإنقاص الوزن للمصـارعين، واستخدم الباحث المنهج التجريبـي باستخدام التصـيم التجريبي ذو القياس القبلي و البعدى على مجموعتين تجريبية وضـابطة وتم اختيار عينة البحث بالطريقة العديـة العشوائية من لاعبى جامعة بنى سويف والبالغ عددهم ( T ) لاعب وذلك بواقع (7) لاعب لكل مجموعة وأسفرت النتائج إلى البرنامج باستخدام التدريب المتقطع عالى الكثافة (Hiit) على تأثير إيجابى على تحسين مستوى اللياقة البدنية وإنقاص الوزن للمصارعين.

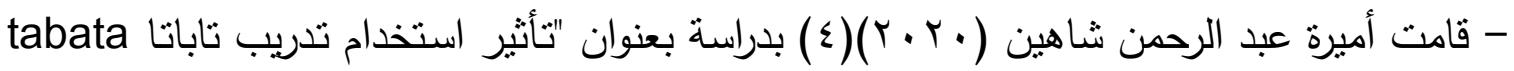
على مستوى الكفاءة الفسيولوجية ومستوى الأداء المهارى فى التنس الأرضى" بهدف التعرف على تأثير برنامج باستخدام تمرينات التاباتا على المتغيرات البدنية والفسيولوجية ومستوى بعض الضربات فى التنس الأرضى، واستخدمت الباحثة المنهج التجريبي باستخدام التصـيم التجريبي ذو القياس القبلي و البعدى على مجموعة تجريبية واحدة وتم اختبار عينة البحث بالطريقة العدية من لاعبى نـادى آاكتوبر والبـالغ عددهم (Y (Y) لاعب ولاعبـة تحت ع ا سـنة وأسفرت النتائج إلى البرنـامج باستخدام تمرينات التاباتا له تأثير ايجابى على تطوير المتغيرات البدنية والفسيولوجية ومستوى بعض الضربات فى التنس الأرضى.

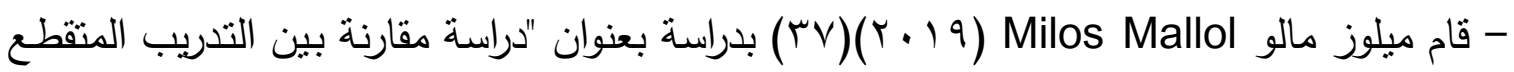
عالي الكثافة منخفض الحجم والتدريب عالي الحجم على مستوى أداء التحمل" بهدف التعرف على تأثثر التدريب المتقطع عالي الكثافة منخفض الحجم، التدريب المتقطع عالي الكثافة عالى الحجم 
على مسـتوى أداء التحمـل وبعـ المتغيـرات الفسـيولوجية، واسـتخدم البـاحثون المـنهج التجريبـي باستخدام التصميم التجربيجي ذو القياس القبلي و البعدى على مجموعتين تجريبيتين واشتملت عينة

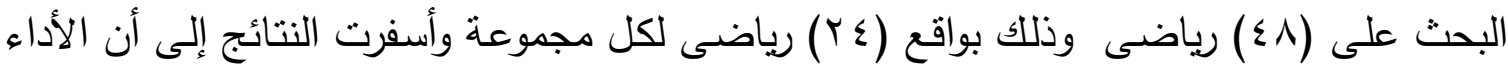
يتحسن فقط مع التدريب (عالي الحجم)، من أجل تحسين أداء الجري أو ركوب الدراجات ، يوصى

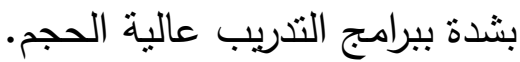

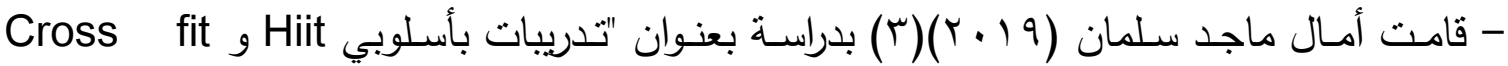
وتأثيرهما ببعض مكونـات اللياقة البدنية- الصحية للنساء بأعمار ( • (-هب)" بهدف التعرف على تأثثر البرنامج بأسلوبي Hiit و Cross fit على بعض مكونـات اللياقة البدنية - الصحية للنساء، واستخدمت الباحث المنهج التجريبي باستخدام التصميم التجريبي ذو القياس القبلي و البعدى على مجموعتين تجريبيـة وضـابطة وبلـغ عددهم (·r) سـيدة بواقع (• ( ) سـيدات لكل مجموعـة ولقد استتتجت الطالبة من خلال دراستها أن التدريب بأسلوبي (Cross fit) و يساعد النساء المتـدربات في تحسـين التركيب الجسـمي لكل مـن تـوازن المكونـات الثناتثة (عضـلات، شـحوم، سوائل)، كذلك مساعدته في تطوير القدرات البدنية لكل من مرونة العمود الفقري، الرشـاقة، التوازن، قوة قبضة الذراع اليمين، وقوة قبضـة الذراع اليسار كما يساعد في تطوير تحمل القوة العضلية لكل من عضلات البطن، الساقين، الذراعين كذلك يعمل على تحسين كفاية الجهازين الدوري والتنفسي.

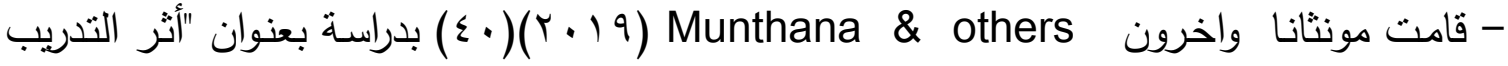
المتقطع عـالى الكثافـة (Hiit) على الأوعيـة الدمويـة والحد الأقصى لاسـتهلاك الاكسـجين" بهدف التعرف على تأثير برنامج التذريب المتقطع عالى الكثافة (Hiit) على الأوعية الدموية والحد الأقصىى لاستهالك الاكستين، واستخدمت الباحثة المنهج التجريبي باستخدام التصميم التجريبي ذو القياس القبلي و البعدى على مجموعتين تجريبية وضابطة وبلغ عددهم (r Y) فتاه وذلك بواقع (l') لاعب لكل مجموعة وأسفرت النتائج إلى البرنامج باستخدام التدريب المتقطع عالى الكثافة (Hiit) له تأثير ايجابى على الأوعية الدموية والحد الأقصى لاستهلاك الاكسجين. - قام أحمد قدرى محمد (Y) (Y) (Y) بدراسة بعنوان "تأثنير برنامج تدريبى فترى عالى الثدة (Hiit) على بعض المتغيرات الصحية لدى السيدات" بهدف التعرف على تأثنر برنامج (Hiit) على بعض 
المتغيرات الصحية لدى السيدات وبعض مكونات الجسم، واستخدم الباحث المنهج التجريبي باستخدام التصميم التجريبي ذو القياس القبلي و البعدى على مجموعة تجريبية واحدة وتم اختيار عينة البحث من عضوات نادى الثمس الممارسين للنشاط الرياضى والبالغ عددهم ( • ( ) سبدات وأسفرت النتائج إلى البرنامج التدريبى فترى عالى الثدة (Hiit) أدى إلى انخفاض فى دهون الدم وتحسن فى معدلات النبض وتحسن فى مكونات الجسم.

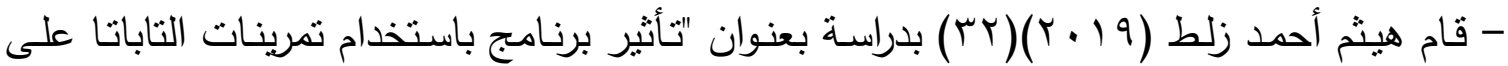
تطوير مستوى الأداء الخططى للافاع والهجوم المضاد للمصارعين" بهذف التعرف على تأثير برنامج باسـتخدام تمرينـات التاباتـا على القدرات البدنيـة الخاصـة ومستوى الأداء الخططى للدفاع والهجوم المضـاد والتعـرف على العلاقـة الارتباطيـة بينهــا، واسـتخدم الباحـث المـنهج التجريبـي باسـتخدام التصميم التجريبي ذو القياس القبلي و البعدى على مجموعتين تجريبية وضـابطة وتم اختيار عينة البحث بالطريقة العمدية العشوائية من منطقة القليوبية والبالغ عددهم ( ·r) لاعب وذلك بواقع (10) لاعب لكل مجموعة وأسفرت النتائج إلى البرنامج باستخدام تمرينات التاباتا لله تأثير ايجابى على تطوير مستوى الأداء الخططى للدفاع والهجوم المضاد للمصارعين.

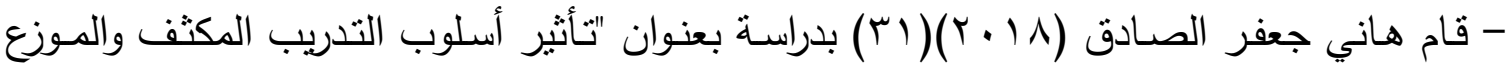
على إتقان تعلم مهارة رفعـة الوسط العكسية في المصـارعة لدى طـلاب كلية التربيـة الرياضية جامعة سوهاج" بهدف التعرف على تأثير أسلوب التدريب المكثف والموزع على إتقان تعلم مهارة رفعـة الوسط العكسية في المصـارعة لدى طـلاب الفرقـة الأولى بكليـة التربية الرياضية - جامعـة سوهاج ، واستخدم الباحث المنهج التجريبي باستخدام التصميم التجريبي ذو القياس القبلي و البعدى على ثلاث مجموعات مجموعتين تجربييتين ومجموعة ضـابطة وتم اختيار عينـة البحث بالطريقة العمدية العشوائية من طلاب الفرقة الاولى بكلية التربية الرياضية جامعة سوهاج والبالغ عددهم

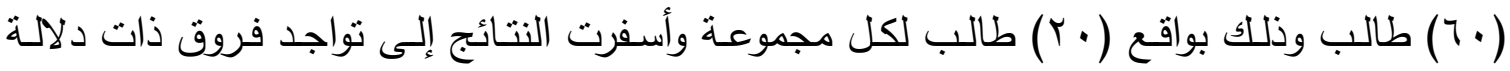
احصائية بين المجموعات الثلاثة في القياسات البعدية لصالح أسلوب التذربب المكثف.

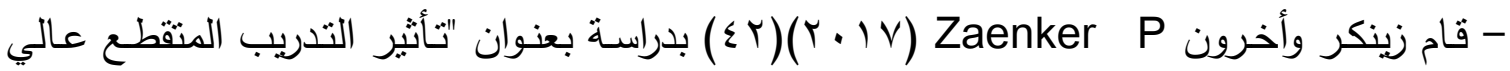
الكثافـة مـع تدريبات المقاومـة على القدرات الفسيولوجية والقوة" بهدف التعرف على تأثثر برنـامج 
التدريب المتقطع عالى الكثافة (Hiit) مع تدريبات المقاومة على الحد الأقصى لاستهلاك الأكسجين ومعدل ضربات القلب والقوة القصوى والقدرة واللاكتات ، والقوة الحركية للعضـات الرباعية وأوتار الركبة، واستخدم الباحثون المنهج التجريبي على مجموعة تجريبية واحدة والبالغ عددهم (T ب) فرد وأسفرت النتائج إلى البرنامج باستخدام التدريب المتقطع عالى الكثافة (Hiit) مـع تدريبات المقاومـة بوزن الجسم أدت إلى تحسن فى الحد الأفصى لاستهلاك الأكسجين ومعدل ضربات القلب والقوة القصوى والقدرة واللاكتات ، والقوة الحركية للعضلات الرباعية وأوتار الركبة وإعادة توازن القوة بين الساقين في عضلات الفخذ.

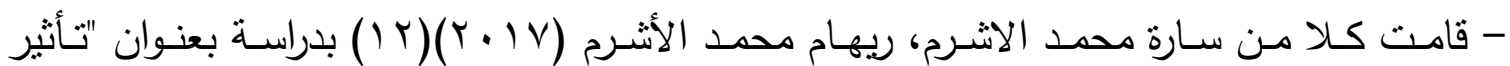
استخدام التدريب المكثف على بعض المتغيرات الفسيولوجية والبدنية الخاصـة بمباراة النقطة الذهبية وفق تعديل قانون رياضة الجودو" بهدف تصميم برنامج تدريبى باستخدام التدريب المكثف والتعرف على تأثنيره على بعض المتغيرات الفسيولوجية والبدنيـة الخاصـة بمباراة النقطـة الذهبيـة فى رياضـة الجودو، واستخدمت الباحثتـان المنهج التجريبـي باسـتخدام التصـميم التجريبي ذو القياس القبلي و البعدى على مجموعة تجريبية واحدة وتم اختيار عينة البحث بالطريقة العمدية العشوائية من لاعبى منتخب جامعة بنى سويف والبالغ عددهم (Y ( ) لاعب وأسفرت النتائج إلى أن التدريب المكثف له تأثنر إيجابى على المتغيرات الفسيولوجية والبدنية قبد البحث .

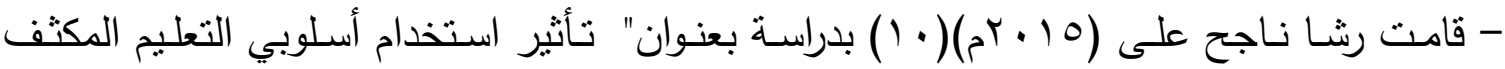
والموزع على إتقان بعض المهارات الحركية في مسابقات الميدان والمضمار ، استهدفت الدراسـة التعرف على تأثثر استخدام أسلوبي التعليم المكثف والموزع على إتقان بعض المهارات الحركية في مسـابقات الميـدان والمضـمار اسـتخدمت الباحثنة المـهـج التجريبـي بتصـميم القيـاس القبلي البعدي للمجموعتين التجريبيتين اشتملت عينـة البحث على طالبـات الفرقـة الثالثة بكليـة التربيـة الرياضية

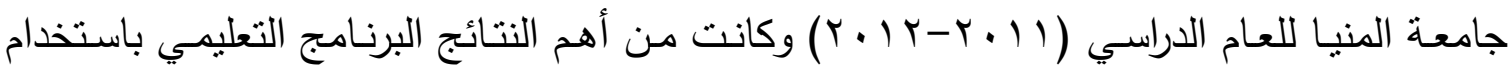
أسلوب ( التعلم المكثف) عن أسلوب ( التعلم الموزع) على مستوى تعلم بعض المهارات في مسابقات

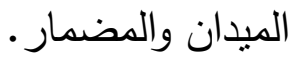




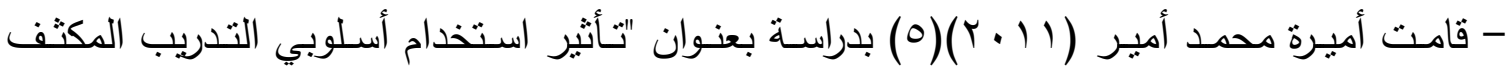
والموزع على إتقان مهارة الإرسال والرضا الحركي في الكرة الطائرة" واستهدفت الدراسـة التعرف على تأثير استخدام أسلوبي التدريب (المكثف - الموزع) والأسلوب التقليدي على مستوى الأداء المهارى في الكرة الطائرة واستخدمت الباحثة المنهج التجريبي للمجموعتين تجريبيين بالإضافة إلى مجموعة ضـابطة واشتملت عينة البحث على طالبات الفرقة الاولى بكلية التربية الرياضية للبنات بالقاهرة

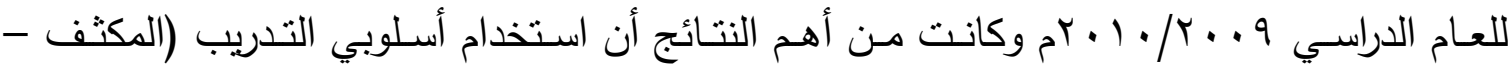
المـوزع) وكذللك الأسـلوب التقليدي لـه تأثيراً إيجابيـا في تعلم مهارة الإرسـال من أعلى (مواجـه (جانبي)

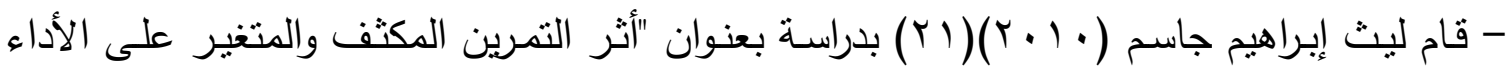
المهارى لمادة كرة اليد في كلية التربية الرياضية جامعة ديالى، يهدف البحث إلى التعرف على أثر أسلوبي التمرين المتغير المكثف والأساليب المتبعة، استخدم الباحث المنهج التجريبي، بلغت العينة ( ع ه) طالبـاً مقسـة إلى مجمـوعين، وكانت أهم النتائج أن المفـردات التطبيقيـة لأسـوب التــرين المتغير المكثف كان لها الأثر الإيجابى في تطوير الأداء المهارى لأفراد العينة التجريبية. - قام رأفت عبد الهادي الكروي (9 . . r)(9) بدراسـة بعنوان "أثر منهج تعليمي بالأسلوب المكثف والموزع في تعلم بعض المهارات الأساسية بكرة القدم للاككور والإناث للفئة العمرية ( - 9 ) سنوات يهدف البحث إلى التعرف على الفروق بين الأسلوبين المكثف والموزع لدى الذكور والإناث، الفروق بين الذكور والإناث في الأسلوب المكثق للقياس البعدي من خلال فرق التأثير، الفروق بين الذكور والإناث في الأسلوب الموزع للقياس البعدي من خلا فرق التأثنر ، استخدم الباحث المنهج التجريبي بأسلوب المجموعات التجربيية المتكافئة لملائمته لطبيعة البحث، تم اختيار عينـة البحث من تلاميذ وتلميذات مدارس الابتدائي (V-9) سنوات بلـن عددهم ( • ( ) تلميذ وتلميذة قام الباحث بتقسيمهم بطريقة عشوائية إلى أربع مجموعات تجريبية كل مجموعة (·r) تلميذ، وكانت أهم النتائج هنالك فروق معنوية بين القياسين القبلي والبعدي للأسلوبين المكثف والموزع لصالح القياس البعدي، هناك فروق بين الذكور والإنـاث في الأسلوب المكثف للقياس البعدي لصـالح الذكور، الأسلوب الموزع للقياس البعدي لصالح الإناث. 
- قام رشـاد طـارق يوسف (1 . . r)(1 (1) بدراسـة بعنوان "أثر التدريب المكثف والموزع بالأسلوبين الثابت والمتغير في تعليم بعض أنواع التهديف بكرة السلة بعدر با -ع ا سنة" يهدف البحث إلى التعرف على تأثير المنهج التعليمي باستخدام التثريب المكثف والموزع بالأسلوبين الثابت والمتغير في تعليم بعض أنواع التهديف بكرة السلة، التعرف على التدريب الأنسب ومـا يحتوبـه من أسلوب في تعليم بعض أنـواع التهديف بكرة السـلة، اسـتخدم الباحث المنهج التجريبي باسـتخدام المجموعـات المتكافئة واختيرت عينة البحث بالطريقة العمديـة من مبتدئي نادي الناصرية الرياضـي بكرة السلة والبالغ عددهم (rr) مبتدئ تم توزبعهم إلى مجموعتين (مجموعة التدريب المكثف ومجموعة التدربب المـوزع، قسمت كل مجموعـة إلى قسمين (الأسـلوب الثابت، والأسـلوب المتغير)، وأهم النتائج أن المنهج التعليمي المعد وفق الأساليب المستخدمة في البحث له تأثير ايجابي وفعال في تعليم بعض أنواع التهديف بكرة السلة، كما أن فترات الراحة لها دور كبير في تعلم مهارة التهديف بكرة السلة، بالإضافة إلي أن التدريب الموزع أظهر تفوقاً ملحوظاً على التدريب المكثق. "إجراءات البحث:

\section{(المنهج)-1}

استخدم الباحث المنهج التجريبي نظراً لمناسبته لطبيعـة البحث ، باستخدام التصميم التجريبي ذو القياس القبلي و البعدى على مجموعتين (تجريبية وضابطة).

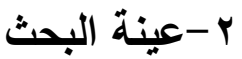

تم اختيـار عينـة البحث بالطريقة العدديـة مـن لاعبي منطقة المنوفيـة (المرحلـة المفتوحسة)

والمسجلين بالاتحاد المصري للمصارعة، حيث بلـغ مجتمع البحث (· (ب) مصارعا تم اختيار ( ( ) مصـارعين لإجراء الدراسـات الاسـطلاعية عليهم، وبـللك تم تطبيق الدراسـة الأساسية على (· (r) مصسارعا وتم تقسيمهم لمجمـوعتين متسـاويتين إحـداهما تجريبيـة والأخـرى ضـابطة بواقـع ( ( ) مصسارعين لكل مجموعة، وجدول ( (1) يوضـح تجانس عينة البحث فى متغيرات (النمو - البدنية . المهارية ـ الفسيولوجية). 


\section{جدول (1)}

$$
\text { تجانس عينة البحث فى متغيرات (النمو - البذنية - المهارية - الفسيولوجية) ن=. ب ب }
$$

\begin{tabular}{|c|c|c|c|c|c|c|c|}
\hline الالتو اء & $\varepsilon^{ \pm}$ & الوسيط & س س & وحدة القياس & \multicolumn{3}{|l|}{ المتغير ات } \\
\hline$\because r V$ & 1.00 & Tr.o & rY.OT & السنة & \multicolumn{2}{|l|}{ السن } & \multirow{4}{*}{ 牙 } \\
\hline .179 & 0.09 & 1100.0 & IVT.TY & سم & \multirow{2}{*}{\multicolumn{2}{|c|}{ 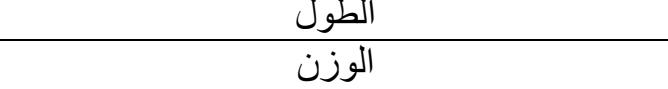 }} & \\
\hline$\cdot r \leqslant \Lambda$ & $7 . V \mathrm{~V}$ & A. & $\vee 9.94$ & كجم & & & \\
\hline$\because \leqslant 9 \leqslant$ & 1.1 & $1 \cdot$ & $1 \cdot . \wedge \mu$ & السنة & \multicolumn{2}{|l|}{ العمر التدريبي } & \\
\hline rrr & 1.97 & rq & Yч.rV & التكر ار & التكر ار فى بق & \multirow{2}{*}{ ت الأداء } & \multirow{10}{*}{ 雪 } \\
\hline $.71 \pi$ &. .49 & $r .7$ & T.Tร & نبضة & زمن العودة • بان/ق & & \\
\hline $1 . \cdot \leqslant V$ & $r \cdot . r)$ & 179 & $170 . V$ & كجم & قوة عضلات الظهر & \multirow{4}{*}{ القصوى القوة } & \\
\hline $1 . r \varepsilon$ & $11 . \mathrm{VV}$ & Tos & ror.IV & كجم & قوة عضلات الرجلين & & \\
\hline .779 & 0.19 & ir. & $119 . \mathrm{VT}$ & باوند با & قوة القبضة يمنى & & \\
\hline דמש. & $0.0 \mathrm{~V}$ & IrT & Irr.q & باوند با & قوة القبضة يسرى & & \\
\hline •.r99 &. ro & 7 & 0.91 & ثانية & \multicolumn{2}{|c|}{ القوة المميزة بالسرعة زمن (َّ) رميات خلفية بالثاخص } & \\
\hline$\cdot r \cdot \varepsilon$ & $\cdot .7 r$ & $1 . .0 \mathrm{~V}$ & $1 . .19$ & ثانية & \multicolumn{2}{|c|}{ الرشاقة زمن أداء الكوبرى (آمرات) } & \\
\hline .90 & V.Yq & $\varepsilon r$ & $\varepsilon \varepsilon .7 \pi$ & سم & الافقية & \multirow{2}{*}{ 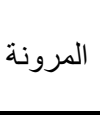 } & \\
\hline. .11 & r.qr & $\leqslant 0$ & $\leq 7 . \cdot r$ & سم & 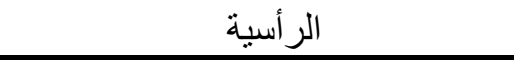 & & \\
\hline $.7 T$ & 1.17 & Tr & TY.TV & تكر ار & \multirow{2}{*}{\multicolumn{2}{|c|}{ العدد الكلى للمهارات داخل الجمل المهارية فى الزمن المن المحدد }} & \multirow{2}{*}{ المهارية } \\
\hline$\cdot$ & .01 & 0.0 & 0.0 & درجة & & & \\
\hline .17 & $1 . \Sigma 1$ & TV & $7 V$ & ن/ق & \multicolumn{2}{|c|}{ معدل النبض فى الر احة } & \multirow{7}{*}{ 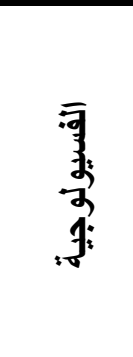 } \\
\hline$\because 9$ &.$\wedge 1$ & 9 & 9.4 & درجة & لدرجة الإنتاج (الخطوات) & منحنى & \\
\hline$\cdot . \Sigma T$ & 1.9 & 14.0 & Ir.r & درجة & درجة سر عة النبض & التعبَّ & \\
\hline$\because \cdot 1$ & T.77 & 09 & $01.0 \mathrm{~T}$ & درجة. & مستوى لياقة الجهاز الدوري و القلب & ل الكارلسون & \\
\hline$\cdot . \wedge r$ & $\because 1 \leqslant$ & r.l & $r .10$ & لتر & \multicolumn{2}{|c|}{ FVC كفاءة الجهاز التنفسى السعة الحيوية FVC } & \\
\hline .19 & ro.ru & $r q$. & $r q \cdot . \wedge r$ & وات في رث & \multirow{2}{*}{\multicolumn{2}{|c|}{ 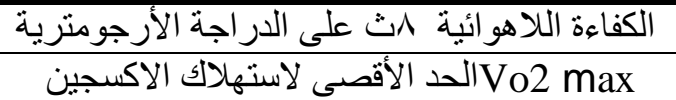 }} & \\
\hline $.7 \varepsilon$ &. $.1 \mu$ & r. & r.I & لتر/ق & & & \\
\hline
\end{tabular}

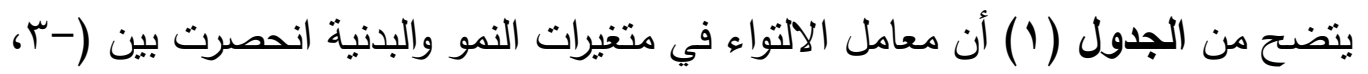
(r+ مما يدل علي تجانس أفراد عينة البحث في هذه المتنغيرات. 


\section{جدول (ץ)}

المتوبط الحسابى والإنحراف المعيارى وقيمة (ت) ودلالتها فى متغيرات(النمو -البدنية-المهارية--

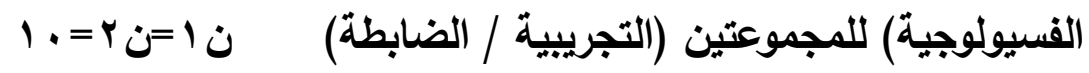

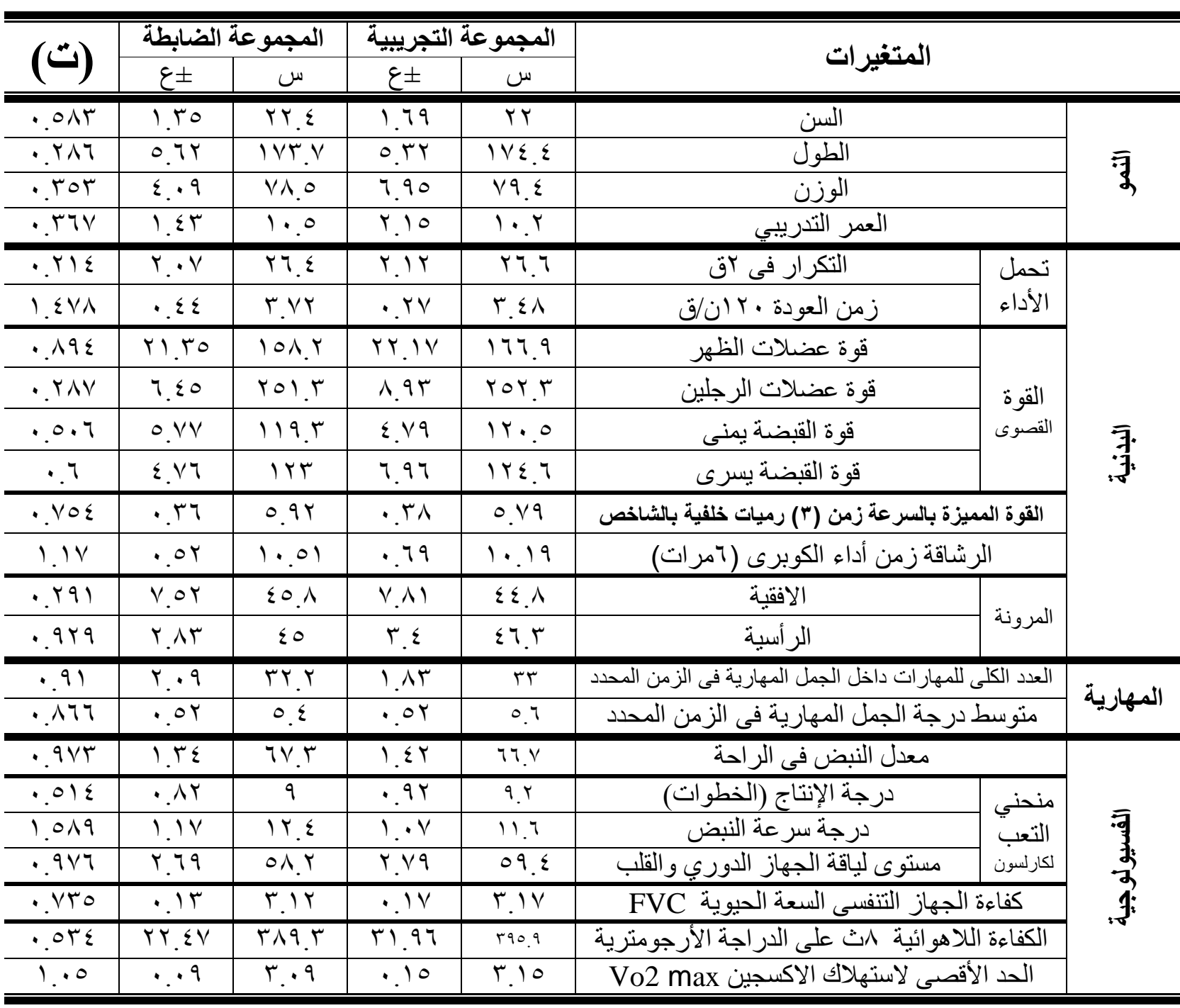

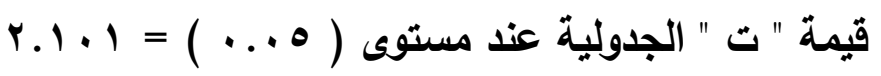

يتضح من الجدول (Y) وجود فروق غير دالة إحصائيا بين المجموعتين(التجريبية / الضـابطة) في المتغيـرات قيــ البحـث ممـا يـدل على تكـافؤ المجمـوعتين في هـذه المتغيـرات حيـث أن قيمـة "ت" المحسوبة أقل من قيمة "ت" الجدولية. 
الأدوات والأجهزة المستخدمة فى جمع البيانات.

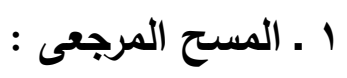

قام الباحث بإجراء مسح للدراسات والمراجع العلمية والمواقع الإلكترونيه التى تتاولت نظم التدريب المتقطع عالي الكثافة فى حدود ما توافرت للباحث وذلك بغرض التعرف على الأساليب والطرق التدريبيـة المختلفة لتلك النظم ، وايضـا الاستفادة منها فى كيفيـة وضـع البرنـامج وتتـكيل الاحمـال والاستفادة من نتائجها فـى مناقثتـة نتائج الدراسـة الحاليـة كذللك تحديــ الزمن المناسب لتطبيقها، وتحديد الاختبارات المناسبة لمتغيرات الدراسة. r) ب استمارة استبيان. مرفق (r) قام الباحث بتصميم استمارة استبيان لاستطلاع آراء الخبراء مرفق ( () فى مجال متغيرات الدراسة من خلال الاتصـال والمقابلات الثخصية لإبداء الرأى فى متغيرات البرنامج والتدريبات الموضوعة وتحديد المتغيرات البدنية والمهارية والفسيولوجية وتحديد الاختبارات المناسبة لقياسها ، وذلك في الفترة

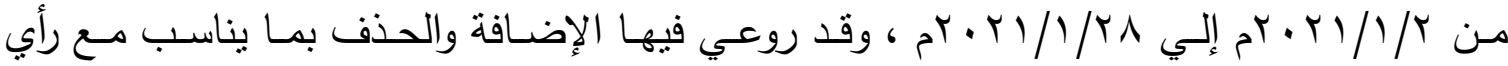
الخبراء.

الاختبارات المستخدة في البحث. مرفق (؛) الاختبارات البدنية تحمل الأداء (التكرار فى كق - زمن العودة • rان/ق)، القوة القصوى (قوة القبضـة يمنى - قوة القبضـة يسرى - قوة عضـلات الرجلين - قوة عضـلات الظهر )، القوة المميزة بالسرعة، الرشـاقة،

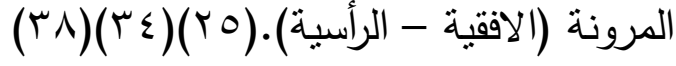

$$
\begin{aligned}
& \text { الاختبارات المهارية (تصميم الباحث) }
\end{aligned}
$$

تقيم الجملة المهارية المحددة في الزمن المحدد (هنكه ثم سنتير ثم برمة) في زمن 0ءث ثم راحـة هاث ويكرر الأداء ثـلاث مـرات (العدد الكلى للمهارات داخل الجمل المهاريـة فى الزمن المحدد، متوسط درجة الجمل المهارية فى الزمن المحدد بناء على تقيم الحكام).

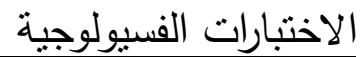


معدل النبض فى الراحة، منحني التعب لكارلسون (درجة الإنتاج \}الخطوات\{ - درجة سرعة النبض - مستوى لياقـة الجهاز الدوري والقلب)، كفاءة الجهاز التنفسى (السعة الحيويـة FVC)، الكفاءة اللاهوائية رث على الاراجة الأرجومترية، الحد الأقصى لاستهلاك الاكسجين Vo2 max

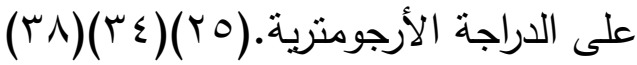

$$
\begin{aligned}
& \text { ع -الأجهزة المستخدمة في البحث. }
\end{aligned}
$$

ميزان إلكتروني لقياس الوزن لأقرب كيلو جرام- ريستاميتز لقياس الأطوال لأقرب سنتيمتر - شريط قياس مدرج لقياس المرونة- ساعة إيقاف لقياس الزمن مقدراً بالثانية ولأقرب ا ـ . • من التانية - ساعة

بـولر - بسـاط مصسارعة- شـواخص مصسارعة متعددة الأوزان - المسانوميتز لقبـاس قوة القبضــة ديناموميتز لقياس قوة عضلات الظهر والرجلين - الدراجة الأرجومترية- جهاز إسبيروميترجاف.

ه-استمارة تسجيل البيانات.مرفق (r)

(•) (البرنامج التدريبي المقترح للمجموعة التجريبية مرفق (1) تم إعداد البرنامج التنريبي بإتباع الخطوات الثالية : قام الباحث بمسح مرجعي للكتب العربية والأجنبية ومواقع الانترنت في حدود علم الباحث. تم إجراء مسـح للبحوث والدراسـات المرتبطـة بمتغيرات البحث في مجـال تدريب رياضــة

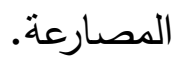
مقابلة والاتصال بالخبراء في مجال المصارعة.

$$
\text { يهدف البرنامج إلى الرئيسي للبرنامج }
$$

تطوير الحالة التدريبية البدنية والمهارة والفسيولوجية للمصارعين عن طريق استخدام اسلوب

$$
\text { - أسس وضع البرنامج }
$$

أ- بناء البرنامج طبقا للأسس العلمية لقواعد اسلوب التدريب المتقطع عالى الكثافة (الهيت HIIT). ب- أن يتتاسب البرنامج التدريبي مع الأهداف الموضوعة . ج- ملائمة البرنامج ومحتوياته من تدريبات للمرحلة السنية للعينة المختارة . 
د- مرونة البرنامج وقابليته للتعديل .

هـ الاستفادة من الدراسات السابقة التي قامت بتصميم برامج ندريبية مشابهه. و - الاستمرارية والانتظام في ممارسة البرنامج التنريبي حتى يعود بالفائدة المرجوة .

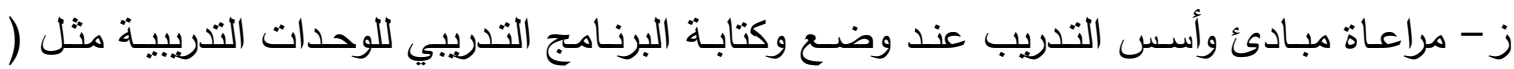

$$
\text { الإحماء- الجزء الرئيسي- الختام ) • }
$$

ح- مراعاة الفروق الفردية عند وضع البرنامج •

ط- ملائمة التدريبات المختارة مع قواعد اسلوب التدريب المنقطع عالى الكثافة (الهيت HIIT). -طريقة تقنين الأحمال التدريبية باسلوب التدريب المتقطع عالى الكثافة (الهيت HIIT). قام الباحث بإجراء مسح للاراسات والبحوث العلمية والمواقع الإلكترونية المرتبطة بموضوع الدراسـة فى ضـوء مـا توفرت للباحث، وذلك للتعرف على خصـائص حمل التدريب وفقا اسلوب التدريب المتقطع عالى الكثافة حيث توصل إلى أن هناك الكثير من الطرق للقيام بنتلك التمارين ولكن

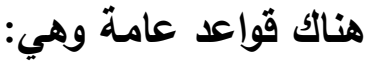

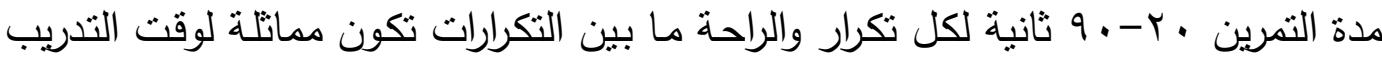
أو يمكن أن تمتد لثلاث أضعاف مدة التمرن أو نصف المدة فإن تمرنت . ثانبة تكون الراحة من • 1 - • ب ثانية وتعتمد فترة الراحة علي شدة وكثافة التمرين ومستوى المتدرب وفى أى مرحلة من مراحل الاعداد، وقت الراحة يتم الوصول فيه لمستوي ضربات قلب هـ٪ أي لا تجعل ضربات القلب تقل عن هذا المعدل العالي. يمكنك أن تظل في مرحلة معينة لأكثر من أسبوعين أو القفز لمرحلة منقدمة في أقل من أسبوعين حسب قدرتك فإن شعرت بالتعود أو أصبحت مرحلة سهلة فاقزز للتي تليها دون تردد.

يمكنك أن تقوم بهذه التمارين في أي مكان وبأي أدوات أيا كان التمرين (بدنى عام أو بدنى خاص أو مهارى) فقط اتبع وقت التدريب إلى وقت الراحة وأيضا الثندة العالية في التمرين. هو شكل معدل من أثنكال التدريب المتقطع، فهي استراتيجية تمارين بفترات متتاوبة قصيرة تتميز بالكثافة مما يجعل الجسم بحاجة إلى كمية اوكسجين أكبر من المعتاد تتبعها فترات 
اسـتراحة قصـيرة جدا، قد تختلف فترة تمـرين HIIT المعتـادة مـن ع إلى • ب دقيقة. هـذه التمرينات المكثفة القصيرة (مثل تمرين عالي الثدة ب دقائق تتبعها ب دقيقة راحة ثم أعادة التمرين والراحة $\wedge$ مرات متتالية)

جلسة الHIIT تتكون من فترة تمارين احمائية تتبع ب ب إلى • ا تمارين عالية الكثافة، ما بين هذه التمارين الحادة يتوجب اجراء تمارين اقل حدة تعتبر فترات استراحة، وتتتهي بفترة حركة هادئة ، منتل المشي ع دقائق ، وليس الجلوس. التمرين عالي الكثافة فكرته أنه يُمارس باقصى شدة مدكنة (حتى "انقطاع النفس" ، أي حتى يصل شدة الإجهاد 90 \% من أعلى مجهود بستطيعه الثخص) ـ التمارين الاقل حدة اللاتي يفصلن التمارين عالية الكثافة يجب ان تكون بشدة • ٪\%، عدد التمارين المكررة وطول كل منها تعتمد على نوع التمرين، لكن يمكن ان يكون بقدر ب تمارين تتضمن · r ثانية فقط من التمرين عالي الكثافة. يتكون تمرين ال HIIT من خليط عدة تمارين لمدة معينة مع فترة راحة محددة، ودائمًا ما يتم ممارسة تلك التمارين لأكثر من دورة واحدة. فعندما يقوم الرياضي بالجرى لمدة • ب ثانية ثم يستريح لمدة • ب ثانية أخرى، فقد أتم دورة واحدة، وعندما يكرر نفس الأمر لمرة أخرى، فقد أتم دورتين كاملتين. وكلما زادت عدد الدورات كلما زادت كثافة الجلسـة الرياضية للوصول إلى (0^\% : . . ٪) من قدرة الرياضـي وهكذا يسير الأمـر • ويُعد المثنال السـابق إحدى صسور تمـارين ال HIIT

$$
\text { بنسبة (نشاط : راحة) تساوي (1:) (1). }
$$

يوصى بعدم القيام بممارسـة تمارين HIIT في أيام منتالية ، إن استخدام أسلوب “الاستشفاء الكامل" أمر مهم للغاية.

قد بيّنت تجارب المتدربين العملية أن أمثل مدة زمنيـة لتمارين ال HIIT تتراوح بين ( • (• ع دقيقة، ولكن لا محالة فإنك ستجد هؤلاء الذين يجهدون أنفسهم لعدة ساعات. على الأرجح فإن هؤلاء لم يتقهموا طبيعة هذا النوع من التمرين الذي يقوم على بذل الطاقة الهوائية بمعدل يفوق 9 \% من قدرة المُتدرب. 
حيث يقومون ببذل 7\% فقط من طاقتهم وربمـا أقل ممـا يمنحهم القدرة على أداء سـاعة

كاملة، وبهذا قد ابتعدوا كل البعد عن الوتيرة السليمة لتمارين ال HIIT. وعلى الغالب فإن هؤلاء الذين يتجاوزون • ب دقيقة لم يستهدفوا طاقتهم بالمعدل الكافي ولم يبذلوا الجهد الكافي، ولم يصلوا لأقصى استفادة من تمارين الHIIT. التدريب المتقطع عالي الكثافة (HIIT) يعتبر نظام لتظيم التدريب القلبي التتفسي، والذي يكون عن طريبق نوبـات متكررة من فترات قصبرة من التمـارين، والتي تتضمن مرات من ممارسـة تمـارين عاليـة الكثافـة متداخلـة مـع فتـرات كثافـة منخفضـة. وعندـ اسـتخدام الحــ الأقصى لمعدل ضربات القلب (MHR) كدليل، يمكن اعتبار الكثافة العالية هي ممارسـة أكثر من ^ ٪ من الحد الأقصى لمعدل ضربات القلب.

مدة البرنامج التدريبى باستخدام الأسلوب المتقطع عالي الكثافة يتراوح من أسبوع : ثلاثة ش شهور عدد الوحدات في الأسبوع يتراوح من وحدتين : أربع وحدات. زمن أداء جرعة التدريب من عق : عق. $(0 r)(01)(\varepsilon V)(\leqslant T)(\leqslant 0)(\leqslant r)(\leqslant r)(\varepsilon \cdot)(r V)(r r)$ محددات البرنامج التدريبي - فترة تنفيذ البرنامـج سوف يتم تتفيذ البرنامج التدريبى المفترح فى فترة الإعداد الخاص وما قبل المنافسات وقد تم تحديد مدة تطبيق البرنامج بـ (1 أسابيع) بواقع (ب وحدات) تدربيية فى الأسبوع على أن بتم تطبيق البرنامج التثريبى المقترح على البساط داخل صالة المصارعة.

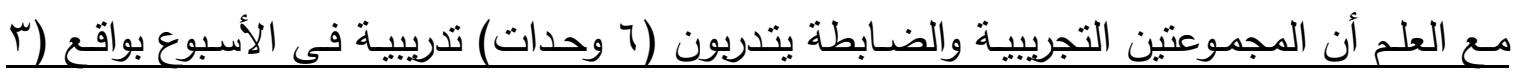

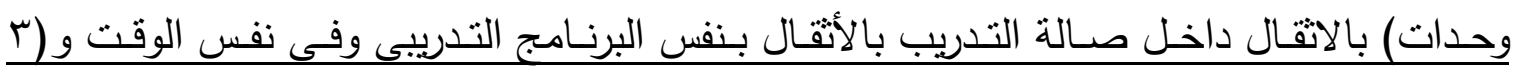
وحدات) الباقيين يكون التدريب على البساط داخل صالة المصارعة ولكن المجموعة التجريبية تتدرب بالبرنـامج التدريبي المقترح بالتدريب المتقطع عـالي الكثافـة والمجموعـة الضـابطة تتدرب بالبرنـامج التقليدى كما يلي: 
جدول (r)

توزيع التدريب الأسبوعى للمجموعتين التجريبية والضابطة

\begin{tabular}{|c|c|c|}
\hline المجموعة الضابطة & المجموعةٌ التجريبيةً & اليوم \\
\hline 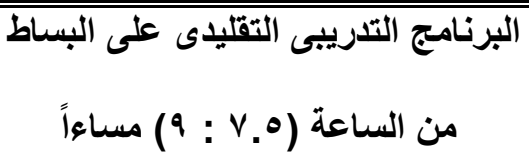 & البرنامج التدريبى المقترح بالتّريب المتقطع عالي & السبت \\
\hline \multicolumn{2}{|c|}{ برنامج التاريب بالاثقال داخل صالة الأثقال من الساعة (^: •.9) مساعاً } & الأحل \\
\hline 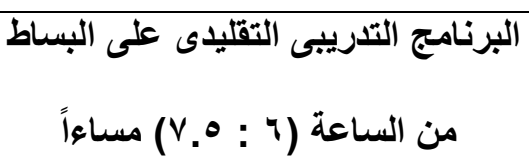 & الكثرنامج التدريبى المقترح بالتدريب المتقطع عالي & الإثنين \\
\hline \multicolumn{2}{|c|}{ برنامج التدريب بالاثقال داخل صالة الأثقال من الساعة (^: ه.9 ) مساءاً } & الثلاثاء \\
\hline 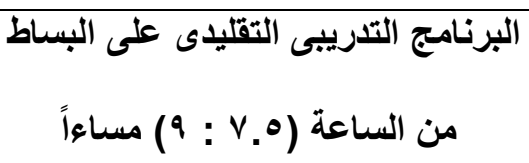 & 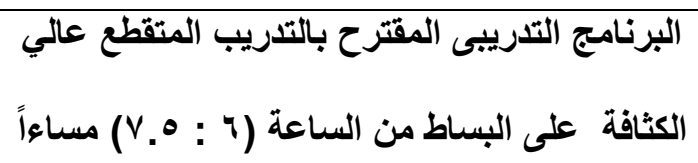 & 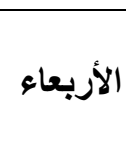 \\
\hline \multirow{2}{*}{\multicolumn{2}{|c|}{ برنامج التدريب بالاثقال داخل صالة الأثقال من الساعة (^: ه.99) مساعاً }} & الخميس \\
\hline & & الجمعة \\
\hline
\end{tabular}

- عدد وحدات البرنامج المقترح (乏 ب وحدة)

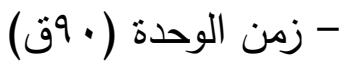

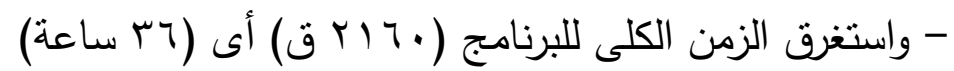

- زمن التدريب داخل الوحدة باستخدام اسلوب التدريب المتقطع عالي الكثافة (بعق)

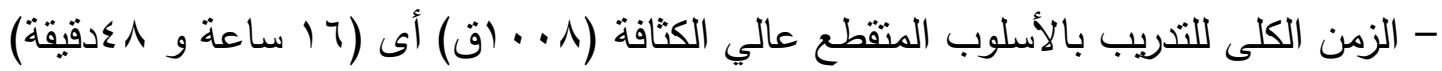

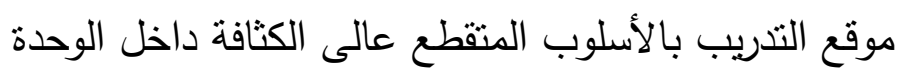
تقسم الوحدة إلى (إحماء - اعداد بدنى عام - اعداد بدنى خاص - اعداد مهارى - اعداد خططى وتتافسى - ختام) - (2) - (2) 


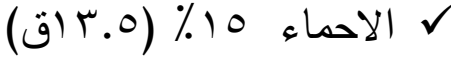

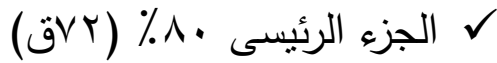

بواقع (r قق) للاعداد العام والخاص والمهارى، (· بقى) للاعداد الخططى والتتافسى

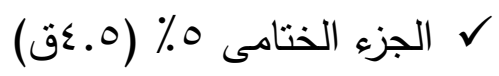

سوف يتم تطبيق الاسلوب المتقطع عالى الكثافة على جزء الاعداد (البدنى عام - البدنى خاص المهارى) داخل الجزء الرئيسى من الوحدة بزمن قدره ( ( عق).

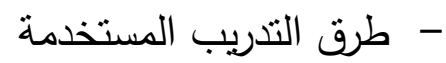
التدريب المتقطع عالي الكثافة - ت تحديد شدة الأحمال التدريبية:

تم تحديد شدة الأحمال التدريبية المستخدمة في البرنامج وفق أسلوب التنريب المتقطع عالي الكثافة حيث تتميز شدة الأداء بالثدة القصوى حيث بلغت الثدة القصوى (.9\% - . . (\%) في ضوء زمن أداء المباراة أى أن زمن المجموعة (7) دقائق حتى يتمانل مع زمن المباراة البرنامج عبارة عن £ مراحل كل مرحلة أسبوعين المرحلة الأولى: (الأسبوع الأول والثانى) يتم التنريب في هذه المرحلة بنسبة (1 : r) واحد تمرين إلى ثلاثة راحة، الزمن الكلى (العمل+الراحة) للمجموعة (اق) مشابه لزمن المباراة. المرحلة الثانية: (الأسبوع الثالث والرابع) يتم التدريب في هذه المرحلة بنسبة (1 : r) واحد تمرين إلى إثثين راحة، الزمن الكلى (العمل+الراحة) للمجموعة (بق) مشابه لزمن المباراة. المرحلة الثالثة: (الأسبوع الخامس والسادس) يتم التدريب في هذه المرحلة بنسبة (1 : ( ) واحد تمرين إلى واحد راحة، الزمن الكلى (العمل+الراحة) للمجموعة (اق) مشابه لزمن المباراة. المرحلة الرابعة والأخيرة: (الأسبوع السابع والثامن) 
يتت التدريب في هذه المرحلة بنسبة (1 : 1/2) واحد تمرين إلى نصف راحة، الزمن الكلى (العمل+الراحة) للمجموعة ( (ق) مشابه لزمن المباراة. جدول (६)

أسس تشكيل حمل التدريب خلال البرنامج اعتمادا علي أسلوب التدريب المتقطع عالي الكثافة في ضوء زمن أداء المباراة أى أن زمن المجموعة (T) دقائق حتى يتماتل مع زمن المباراة

\begin{tabular}{|c|c|c|c|c|c|c|c|}
\hline نوعية & للعبة & المجين & المجموعا & التكرارات & زالتمن أداء & التكرارات & الأسبوع \\
\hline \multirow{3}{*}{ خاحة نشطة } & $r: 1$ & اق & $r: 1$ & & هاث & 7 & الأول \\
\hline & $r: 1$ & اق & $r: 1$ & ث & هاث & 7 & الثانى \\
\hline & $r: 1$ & اق & $r: 1$ & • . & ثr. & 7 & الثالث \\
\hline \multirow{2}{*}{ وإطالات (مشي } & $r: 1$ & اق & $r: 1$ & • & ثr. & 7 & الرابع \\
\hline & $1: 1$ & اق & $r: 1$ & • سث & . & 7 & الخامس \\
\hline \multirow{3}{*}{ تمبرينات } & $1: 1$ & اق & $r: 1$ & • سث & • rث & 7 & السادس \\
\hline & $1 / 2: 1$ & اق & $r: 1$ & ثr. & ث & 7 & السابع \\
\hline & $1 / 2: 1$ & اق & $r: 1$ & ثr. & ث . & 7 & الثامن \\
\hline
\end{tabular}

- تقنين شدة الأحمال التدريبية:

تم تقنين شـدة الأحمال التدربيية باستخدام معدل النبض، بتطبيق المعادلة التالية: النبض

$$
\begin{aligned}
& \text { المستهدف للتدريب THR : (1: (1) : (1) } \\
& \text { = نبض الراحة + [ نسبة التدريب x ( أقصي نبض - نبض الراحة ) ] حيث: } \\
& \text { • متوسط عمر العينة = r م سنة. } \\
& \text { • متوسط نبض الراحة للعينة = TV ن/ق. }
\end{aligned}
$$

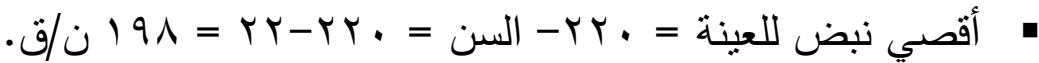

$$
\begin{aligned}
& \text { • احتياطي النبض للعينة = أقصي معدل للنبض - معدل النبض في الراحة }
\end{aligned}
$$




$$
\text { . }
$$

تقنين الأحمال التدربيية باستخدام معدل النبض

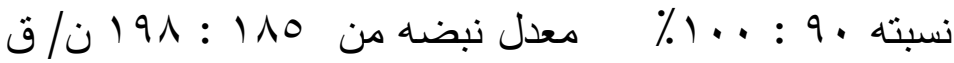

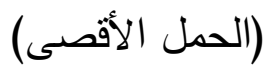

\section{أجزاء الوحدة التدريبية}

تتكون الوحدة التدرييية من الأجزاء الآتيـة حسب الترتيب [الإحماء بنسبة 10\% ثم الجزء الرئيسى بنسبة .^٪ ويشمل (البدنى ثم المهارى) ثم الختام بنسبة \%٪]. 1-الإحماء

يهدف هذا الجزء من الوحدة التدريبية بصفة أساسية إلى إعداد وتهيئة اللاعب من جميع النواحي للجزء الرئيسي من الوحدة والعمل على إكساب العضلات المرونة والمطاطية اللازمة والعمل على

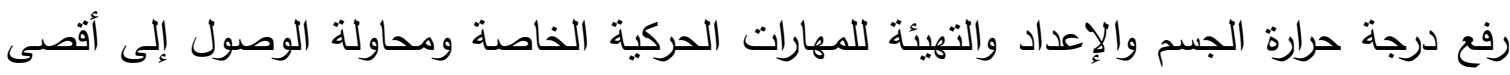
قدرة استجابية لرد الفعل والتزكيز على مراجعة مسار المهارات التي سوف تؤدى بعد ذلك.

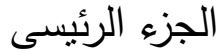
r-إلإعداد البدنى العام ويتضمن هذا الجزء على تدريبات العامة بالوحدة التدريبية ويتم التدريب عليها فى ضوء أسلوب التدريب المتقطع عالى الكثافة عن طريق الأداء بأقصى شدة ممكنة وتتبعها فترات راحة قصيرة وهى عبارة عن تدريبات عامة تخدم القدرات البدنية عن طريق تمرينات المقاومة والتدريبات الفردية والزوجية والتثريبات التنافسية. ب- ب الإعداد البدنى الخاص ويتضمن هذا الجزء على ندريبات خاصة بالوحدة التدريبية ويتم التدريب عليها فى ضوء أسلوب

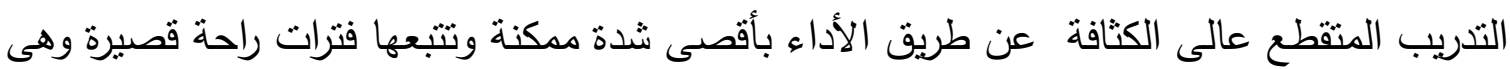
عبارة عن تدريبات تخدم القدرات البدنية الخاصة والعضلات العاملة وفى اتجاه المسار الحركى وتتثابه فى مكوناتها وأهدافها مع متطلبات النشاط التخصصى عن طريق تمرينات المقاومة والتدريبات الخاصة الفردية والزوجية والتدريبات التتافسية والتى تتثابه فيها العمل العضلى مع منطلبات الأداء المهارى وفى نفس المسار الحركي. 


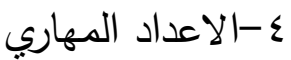

يحتوى هذا الجزء من الوحدة على التدريبات الخاصة بتتمية المهارات الحركية ويتم التدريب عليها فى ضوء أسلوب التدريب المتقطع عالى الكثافة عن طريق الأداء بأقصى شدة ممكنة وتتبعها فترات راحة قصيرة عن طريق الأداء وفق مقاومات مختلفة باستخدام الأساتيك المطاطة ورداء الأثقال وطوق اثقال اليدين والرجلين والتدريب على شواخص مختلفة الأوزان والاطوال ومع لاعبين مختلفة الأوزان والاطوال.

$$
\text { 0- الاعداد الخططى والتتافسى }
$$

يحتوى هذا الجزء من الوحدة على خطط اللعب وخطط الهجوم والهجوم المضاد والتكتيك الخاص باللاعب ويحتوى على المباريات التنافسية القانونية والمشروطة من وضعى الصراع من أعلى ومن

يهدف هذا الجزء من الوحدة التدربيية إلى محاولة العودة باللاعب إلى حالته الطبيعية أو ما يقرب منها بقدر الإمكان وذللك بعد المجهود المبذول وفى هذا الجزء يتم استخدام تمرينات الاسترخاء والتي ينخفض فيها مقدار الحمل. * البرنامج التدريب؟ التقليلى * الإحماء

يهدف هذا الجزء من الوحدة التدريبية بصفة أساسية إلى إعداد وتهيئة الفرد والعمل على إكساب العضالات المطاطية اللازمة والعمل على رفع درجة حرارة الجسم.

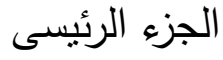

وبرتب كالتالى (الاعداد العام- الاعداد الخاص-الاعداد المهارى) ويشتمل على الاعداد العام لعناصر اللياقة البدنية العامة ثم الانتقال إلى التدريب على العناصر الخاصة بالمصارعة ثم الانتقال إلى الجزء المهارى والتدريب على المهارات بشكل منفرد مع الزميل فى زمن محدد ثم الانتقال إلى الجزء التتافسى عن طريق التدريب التقليدى بطريقة التدريب الفترى . 
يهدف هذا الجزء من الوحدة التدريبية إلى محاولة العودة بالفرد إلى حالته الطبيعية أو ما يقرب منها بقدر الإمكان. الاراسات الاستطلاعية

قام الباحث باختيار عينة عشوائية من مجتمع البحث قوامها (• () لاعبين من خارج عينة البحث الأساسية ، وأجري عليهم الاختبارات بمعاونة المساعدين ، وذلك من يوم ، / / / • بم :

$$
\text { اللهدف من هذه الاراسة }
$$

ك التأكد من سلامة تتفيذ وتطبيق القياسات والاختبارات وصصلاحية الأجهزة والأدوات وما يتعلق من إجراءات وفقا للشروط الموضوعة لها ومدي مناسبة أماكن القياس والتدريب.

ـ تحديد الزمن اللازم لعملية القياس والزمن الذي يستغرقه كل لاعب لكل اختبار عند القياس. Ł التعرف على الأخطاء التي يمكن الوقوع فيها أثناء تتفيذ الاختبارات والقياسات وترتيب سيرها ومدى ملائمتها للمرحلة السنية. Ł الوصول لأفضل ترتيب لإجراء الاختبارات. Ł شرح طريقة أداء التدريب باستخدام اسلوب التدريب المتقطع عالى الكثافة والتأكد من مدى مالائمة التدريبات المختارة للعينة قيد البحث. وتم التأكد من مناسبة الاختبارات لعينة البحث وكذلك الأدوات ومكان إجراء القياسات ، بالإضافة إلى التأكد من إلمام المساعدين لكيفية إجراء الاختبارات لتلافي أخطاء القياس. المعاملات العلمية للاختبارات المستخدمة

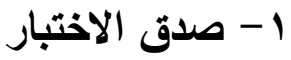




\section{جدول (0)}

دلالة الفروق بين المجموعتين (المميزة وغير المميزة) في الاختبارات قيد البحث ن ا=ن ؟ =( • (1)

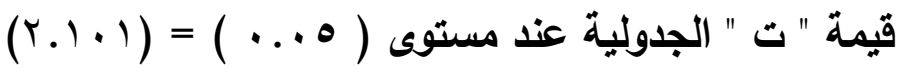

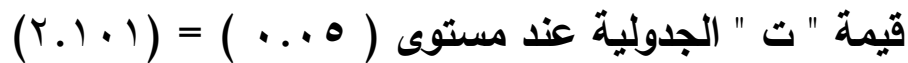

\begin{tabular}{|c|c|c|c|c|c|c|c|}
\hline \multirow{2}{*}{$(\omega)$} & \multicolumn{2}{|c|}{ المجموعة الغير مميزة } & \multicolumn{2}{|c|}{ المجموعة المميزة } & \multirow{2}{*}{\multicolumn{3}{|c|}{ المثخيز اث }} \\
\hline & $\varepsilon \pm$ & س & $\varepsilon \pm$ & س & & & \\
\hline$* \varepsilon .9 \wedge 1$ & $1 . \%$ & rr.o & $1 . \wedge 0$ & YT. & التكر ار فى بق & \multirow{2}{*}{ تحمل الأداء } & \multirow{10}{*}{ 寻 } \\
\hline *E.ATr &.$r$ & $\varepsilon . \varepsilon \wedge$ & 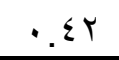 & r.VT & زمن العودة • ب ان/ق & & \\
\hline$* \varepsilon . \wedge 9 \wedge$ & & (ז. & 17.11 & $1 V \cdot .1$ & قوة عضلات الظهر & \multirow{4}{*}{ القوى - القوة } & \\
\hline *T.人 & $\varepsilon 1 . \Gamma \varepsilon$ & $Y 11.7$ & $1 \varepsilon . \varepsilon$ & Yาะ. 9 & قوة عضلات الرجلين & & \\
\hline *Y.orq & $7 . \wedge \wedge$ & IT. & 0.17 & 119.5 & قوة القبضة يمنى & & \\
\hline$*$ * $\leq 0 \leq$ & 0. ro & 11r. & $\varepsilon . V$ & $1 \times 1.1$ & قوة القبضة بسرى & & \\
\hline$* 7 . Y 10$ & 17 & $7 . \mathrm{V}$ & $\cdot r$ & 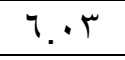 & \multicolumn{2}{|c|}{ القوة المميزة بالسر عة زمن (r) رميات خلفية بالثاخص } & \\
\hline$* r .0 .9$ & $.0 \leqslant$ & $11.1 \varepsilon$ & .70 & $1 \cdot . \leqslant V$ & \multicolumn{2}{|c|}{ الرشاقة زمن أداء الكوبرى (آمرات) } & \\
\hline *T. & r. $\wedge \varepsilon$ & 01.7 & $V .9$ & (1) & الافقية & \multirow{2}{*}{ 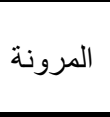 } & \\
\hline *0.1 & $1 . \wedge 1$ & $\leqslant 1 . \wedge$ & $r . \varepsilon q$ & $\leqslant 7 . \wedge$ & الر أسية & & \\
\hline$* \vee . \wedge 91$ & .79 & r^.乏 & $1 . V$ & 1. & \multirow{2}{*}{\multicolumn{2}{|c|}{ 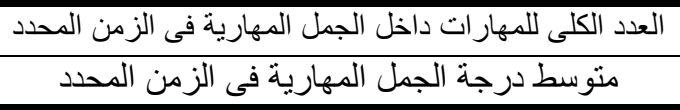 }} & \multirow{2}{*}{ المهارية } \\
\hline$* 0 . \mu \cdot \Lambda$ & $\because \Sigma \Lambda$ & $\varepsilon . \mu$ & .04 & 0.0 & & & \\
\hline$* \varepsilon .17$ & 1.1 & 79 & 1.07 & $7 V$ & \multicolumn{2}{|l|}{ معدل النبض فى الراحة } & \multirow{7}{*}{ 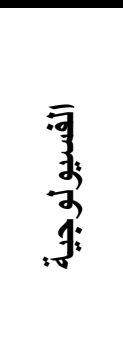 } \\
\hline$* \% .9 \wedge 1$ & I.rt & $1 \cdot .1$ &.$V \varepsilon$ & 1.9 & ل درجة الإنتاج (الخطو ات) & \multirow{3}{*}{ لكنحني } & \\
\hline 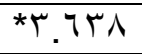 & .99 & $1 \leq .1$ &.$\wedge \varepsilon$ & $1 T .7$ & درجة سر عة النبض & & \\
\hline$* \varepsilon .1 \wedge 0$ & $\varepsilon . \leqslant V$ & 01.1 & Y.OS & $0 \wedge$ & مستوى لياقة الجهاز الدوري و القلب & & \\
\hline$*\rceil . \wedge \vee 1$ & .1 & Y.VA & $.1 \varepsilon$ & 1.10 & \multicolumn{2}{|c|}{ كفاعة الجهاز التنفسى السعة الحيوية FVC } & \\
\hline$* \eta \cdot V$ & $\varepsilon .0$ & $r \leqslant r . \Lambda$ & YY.Yq & rAV.r & \multicolumn{2}{|c|}{ الكفاءة اللاهو ائية رث على الدراجة الأرجومترية } & \\
\hline$* V . \wedge r q$ & $\because 1$ & Y.A & $\cdot .11$ & r.IV & \multicolumn{2}{|c|}{ الحد الأقصى لاستهلاك الاكسجين Vo2 max } & \\
\hline
\end{tabular}

قام الباحث بحساب صدق التمييز بين مجموعتين إحداهما غير مميزة من خارج عينة البحث

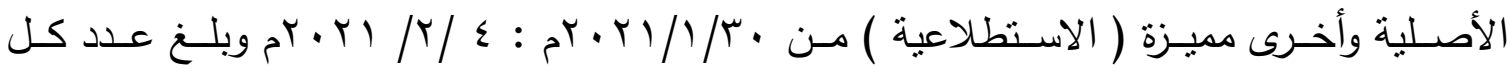

$$
\text { مجموعة (· ( ) مصارعين. }
$$

يتضح من جدول (0) وجود فروق دالة إحصائيا لصالح المجموعة المميزة مما يشير إلى

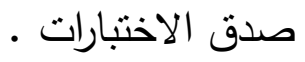

-ثبات الاختبارات :قام الباحث بحساب ثبات الاختبارات باستخدام إعادة الاختبارات على عينـة

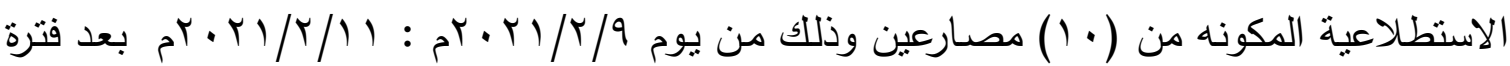
زمنية فاصلة قدرها أسبوع بين النطبيقين 


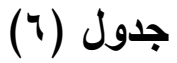

المتوسط الحسابى والإنحراف المعيارى ومعامل الإرتباط

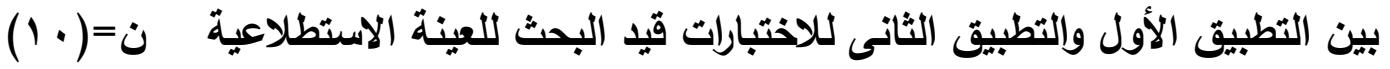

\begin{tabular}{|c|c|c|c|c|c|c|c|}
\hline \multirow{2}{*}{$(\jmath)$} & \multicolumn{2}{|c|}{ تطبيق ثُانى } & \multicolumn{2}{|c|}{ تطبيق أول } & \multirow{2}{*}{\multicolumn{3}{|c|}{ المتغير ات }} \\
\hline & $\varepsilon \pm$ & س & $\varepsilon \pm$ & س & & & \\
\hline$\cdot V \varepsilon$ & 1.11 & r7.0 & 1.10 & r..1 & التكر ار فى بق & \multirow{2}{*}{ تحمل الأداء } & \multirow{10}{*}{ 高 } \\
\hline$\cdot .99$ & • & $r .79$ & $\cdot . \varepsilon r$ & $r . V \mu$ & زمن العودة · ب ان/ق & & \\
\hline. .99 & 17.97 & $1 V \cdot . \varepsilon$ & 17.11 & $1 V \cdot .1$ & قوة عضلات الظهر & \multirow{4}{*}{ القصوى القوة } & \\
\hline 1 & $11 . \vee 9$ & r70.r & $1 \varepsilon . \cdot \varepsilon$ & rาะ. 9 & قوة عضلات الرجلين & & \\
\hline$\cdot .99$ & $0.0 \varepsilon$ & 119.7 & 0.17 & $119 . \varepsilon$ & قوة القبضة يمنى & & \\
\hline$\cdot .99$ & $\varepsilon . \leqslant Y$ & $|r| . r$ & $\varepsilon . V$ & $|r| .1$ & قوة القبضة بسرى & & \\
\hline. .99 & $\cdot r$ & $7 . r$ & $\cdot . r$ & 7.4 & \multicolumn{2}{|c|}{ القوة المميزة بالسرعة زمن (َّ) رميات خلفية بالثاخص } & \\
\hline 1 &. .70 & $1 \cdot . \leqslant 7$ & $\cdot .70$ & $1 \cdot . \leqslant V$ & \multicolumn{2}{|c|}{ الرشاقة زمن أداء الكوبرى (آمرات) } & \\
\hline 1 & $7 . \wedge \varepsilon$ & $\varepsilon r . r$ & $V .9$ & $\varepsilon r . \mu$ & الافقية & \multirow{2}{*}{ 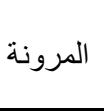 } & \\
\hline. .99 & t.ru & $\leq 7.9$ & r. $\leqslant 9$ & $\leq 7.1$ & الر أسية & & \\
\hline .90 & .90 & TI.V & $1 . V$ & $T .7$ & \multirow{2}{*}{\multicolumn{2}{|c|}{ 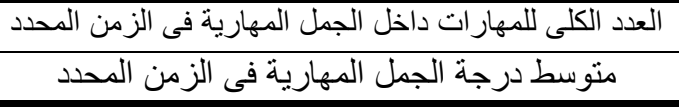 }} & \multirow{2}{*}{ المهارية } \\
\hline..$\wedge 1$ & $.0 Y$ & 0.7 & $.0 \mathrm{Or}$ & 0.0 & & & \\
\hline$\cdot .91$ & $1 . \leqslant 0$ & 77.9 & 1.07 & $7 V$ & \multicolumn{2}{|l|}{ معدل النبض فى الراحة } & \multirow{7}{*}{ 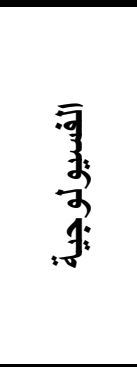 } \\
\hline .9 & $.7 \mathrm{~V}$ & 9 &.$V \varepsilon$ & 1.9 & درجة الإنتاج (الخطو ات) & & \\
\hline. .94 & $\cdot .10$ & IY.O & $\cdot . \wedge \varepsilon$ & $1 Y .7$ & درجة سر عة النبض & 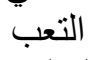 & \\
\hline 1 & r.os & $0 \wedge$ & Y.os & 01 & مستوى لياقة الجهاز الدوري و القلب & لكارلسون & \\
\hline$\cdot .17$ & $.1 Y$ & 5.11 & $\because 1 \varepsilon$ & 5.10 & \multicolumn{2}{|c|}{ كفاءة الجهاز التنفسى السعة الحيوية FVC } & \\
\hline. .99 & r1.9r & 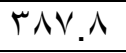 & rY.rq & rᄉV.r & \multirow{2}{*}{\multicolumn{2}{|c|}{ 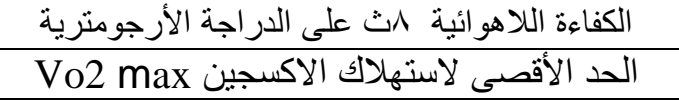 }} & \\
\hline$\cdot . \wedge \varepsilon$ & $\because .1 Y$ & $r . r$ &. $.1 T$ & $r .1 \mathrm{~V}$ & & & \\
\hline
\end{tabular}

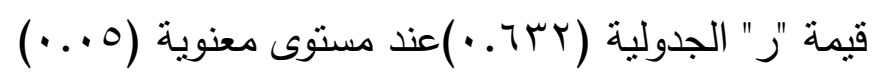

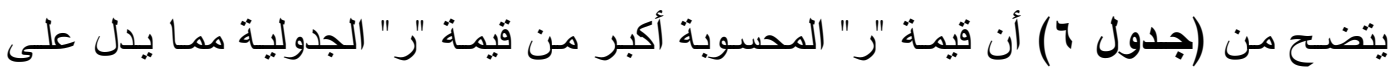

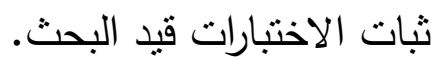

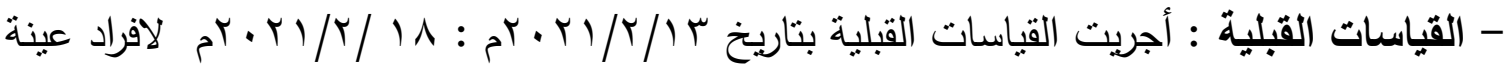

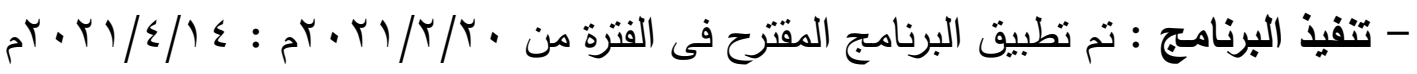

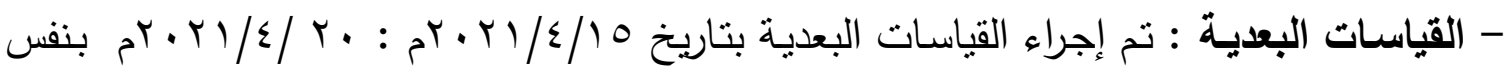
شروط ومواصفات القياس القبلى وبنفس المكان. 


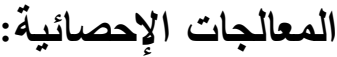

وقد استعان الباحث فى معالجة بيانات هذه الدراسة بالعمليات الإحصائية التالية:

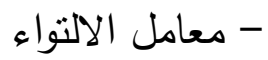

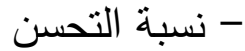

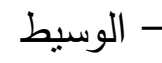

- اختبار دلالة الفروق (ت) - (تر)
- الوسط الحسابى - الانحراف المعيارى

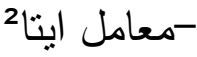

عرض ومناقشية النتائج

أولا عرض النتائج

دلالة الفروق بين القياس (القبلي/البعدى) للمجموعة التجريبية

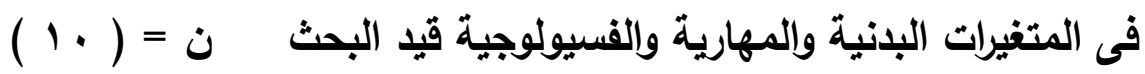

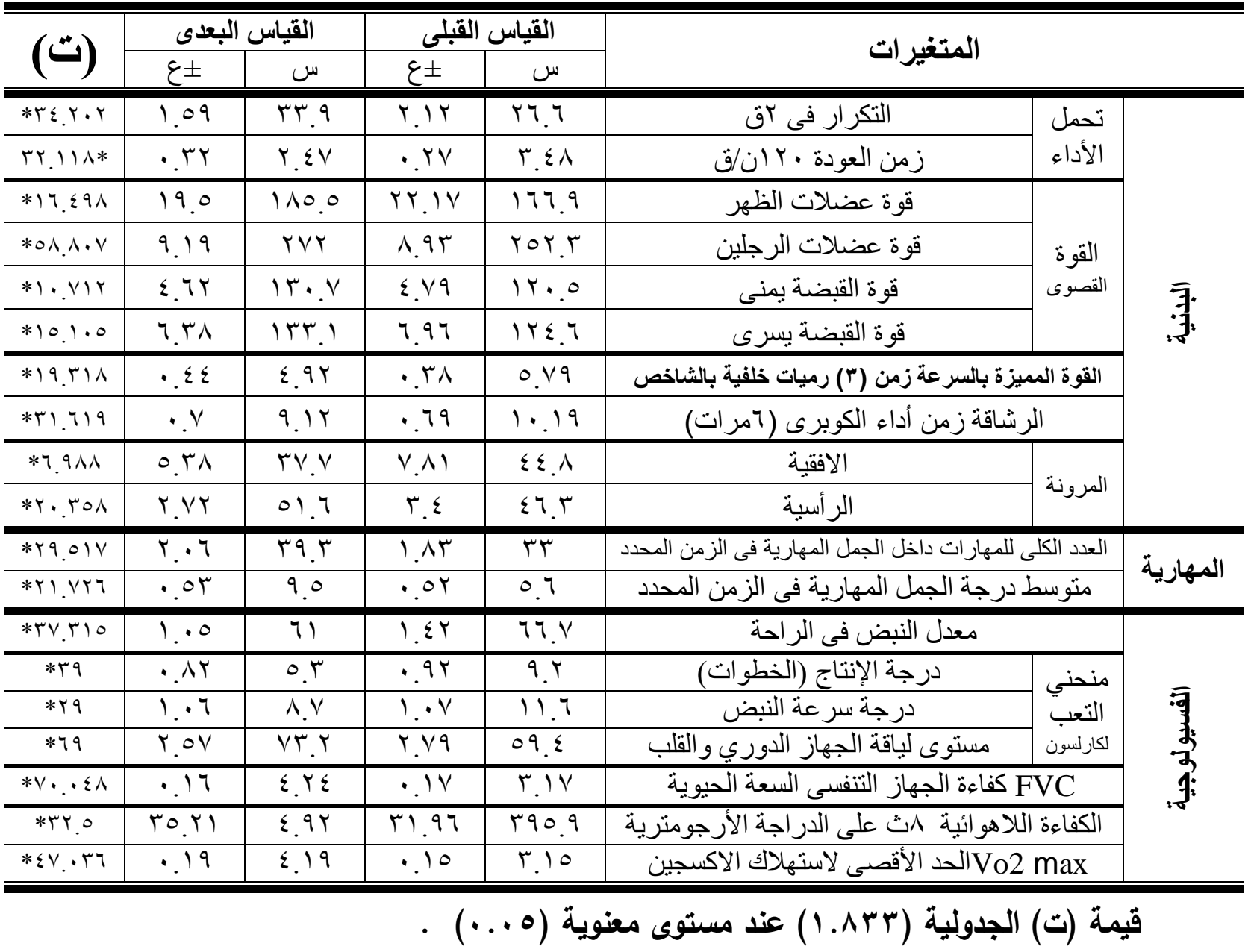


يتضح من جدول (V) وجود فروق دالة احصائية بين القياسين القبلي والبعدي للمجموعة التجريبية لصالح القياس البعدي في المتغيرات البدنية والمهارية والفسيولوجية قيد البحث حيث ان قيمة اختبار (ت) المحسوبة اعلي من قيمة (ت) الجدولية لجميع المتغيرات.

\section{جدول (^)}

دلالة الفروق بين القياس (القبلي/البعدى) للمجموعة الضابطة فى المتغيرات البدنية والمهارية والفسيولوجية قيد البحث ن = ( ( )

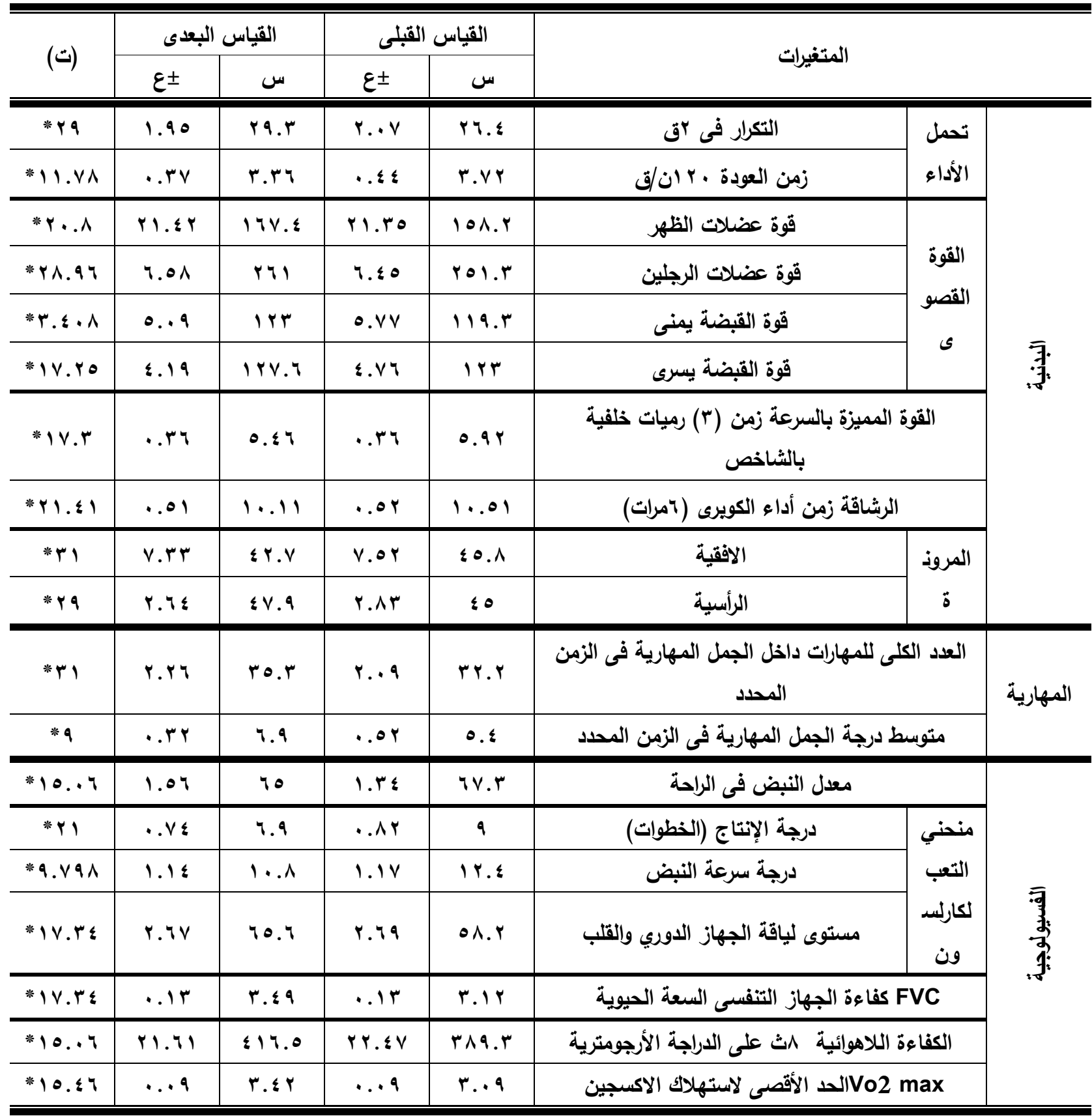


قيمة (ت) الجدولية (بrA. 1.) عند مستوى معنوية (ه ...)

جدول (^)

دلالة الفروق بين القياس (القبلي/البعدى) للمجموعة الضابطة

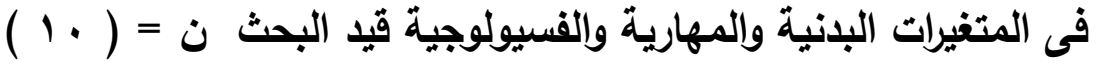

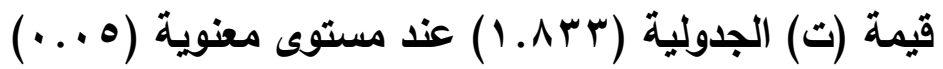

\begin{tabular}{|c|c|c|c|c|c|c|c|}
\hline \multirow{2}{*}{$(\uplus)$} & \multicolumn{2}{|c|}{ القياس البعدى } & \multicolumn{2}{|c|}{ القياس القبلى } & \multirow{2}{*}{\multicolumn{3}{|c|}{ المتغيرات }} \\
\hline & $\varepsilon \pm$ & س & $\varepsilon \pm$ & س & & & \\
\hline *ץq & 1.90 & rq.r & $r . \cdot V$ & Y.. & التكر ار في بق & \multirow{2}{*}{ تحمل } & \multirow{10}{*}{ 高 } \\
\hline$* 11 . \vee \wedge$ & $\cdot r V$ & 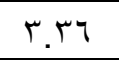 & $\cdot . \varepsilon \varepsilon$ & r.Vt & زمن العودة · ب ان/ق & & \\
\hline$* Y \cdot . \Lambda$ & r). $\leqslant r$ & $17 V . \varepsilon$ & Y) & $101 . Y$ & قوة عضلات الظهر & \multirow{4}{*}{ القصوى القوة } & \\
\hline *Y人.97 & 7.01 & (4T) & $7 . \leqslant 0$ & rol.r & قوة عضلات الرجلين & & \\
\hline$* \varphi . \varepsilon \cdot \Lambda$ & 0.9 & זr & $0 . V V$ & 119.4 & قوة القبضة يمنى & & \\
\hline *IV.ro & $\{.19$ & ITV.T & $\Sigma . \vee 4$ & שזו & قوة القبضة يسرى & & \\
\hline *IV.r &. .4 & 0.57 &.$\mu$ & 0.94 & \multicolumn{2}{|c|}{ القوة المميزة بالسرعة زمن (َّ) رميات خلفية بالشاخص } & \\
\hline *YI. \&1 & .01 & $1 \cdot .11$ & $.0 \mathrm{r}$ & $1 . .01$ & \multicolumn{2}{|c|}{ الرشاقة زمن أداء الكوبرى (آمرات) } & \\
\hline *T1 & V.r & $\varepsilon r . V$ & V.Or & $\leq 0 . \wedge$ & الافقية & \multirow{2}{*}{ 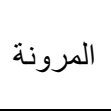 } & \\
\hline *ץq & T.Tะ & $\leq \vee .9$ & r.ی & «o & الر أسية & & \\
\hline * & Y.YT & ro.r & $r .9$ & TY.Y & \multirow{2}{*}{\multicolumn{2}{|c|}{ العدد الكلى للمهار ات داخل الجمل الجمل المهارية في الزمه الزمن المحدد }} & \multirow{2}{*}{ المهارية } \\
\hline$* q$ & 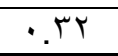 & 7.9 & $.0 Y$ & $0 . \varepsilon$ & & & \\
\hline$* 10.7$ & 1.07 & 70 & $1 . r \varepsilon$ & $T V . r$ & \multicolumn{2}{|c|}{ معدل النبض في الر احة } & \multirow{7}{*}{ 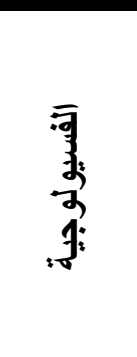 } \\
\hline *ץ &.$V \varepsilon$ & 7.9 & $\cdot . \wedge r$ & 9 & درجة الإنتاج (الخطو ات) & منحن & \\
\hline$* 9 . \vee 91$ & $1.1 \varepsilon$ & $1 \cdot .1$ & $1.1 \mathrm{~V}$ & $1 Y . \varepsilon$ & درجة سرعة النبض & التعب ي & \\
\hline *IV.TE & Y.TV & 70.7 & r.79 & $0 \Lambda . Y$ & مستوى لياقة الجهاز الدوري و القلب & لكارلسون & \\
\hline *IV.TE & .11 & $r . \leqslant q$ &. .15 & r.IT & \multicolumn{2}{|c|}{ كفاءة الجهاز التنفسى السعة الحيوية FVC } & \\
\hline$* 10.9$ & YI.T1 & $\$ 17.0$ & YY. $\varepsilon V$ & $r \wedge 9 . r$ & \multirow{2}{*}{\multicolumn{2}{|c|}{ 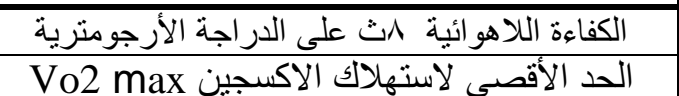 }} & \\
\hline *10.57 & $\because .9$ & $r . \varepsilon r$ & $\because 9$ & $r .9$ & & & \\
\hline
\end{tabular}

يتضح من (جدول ^) وجود فروق دالة احصائية بين القياسين القبلي والبعدي للمجموعة الضابطة لصالح القياس البعدي في المتغيرات البدنية والمهارية والفسيولوجية قيد البحث حيث ان قيمة اختبار (ت) المحسوبة اعلي من قيمة (ت) الجدولية لجميع المتغيرات. 


\section{جدول (9)}

دلالة الفروق بين القياسين البعديين للمجموعتين التجريبية والضابطة

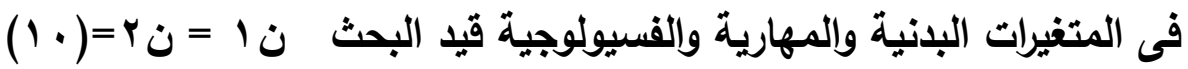

\begin{tabular}{|c|c|c|c|c|c|c|c|}
\hline & \multicolumn{2}{|c|}{ المجموعة الضابطة } & \multicolumn{2}{|c|}{ المجموعة التجريبية } & \multirow{2}{*}{\multicolumn{3}{|c|}{ المتغير ات }} \\
\hline & $\varepsilon \pm$ & س & $\varepsilon \pm$ & س & & & \\
\hline *0.VA & 1.90 & rq.r & 1.09 & r. & التكر ار فى بق & \multirow{2}{*}{ ت ت الأداء } & \multirow{10}{*}{ 雪: } \\
\hline *O.VIT & $\cdot r v$ & דr. & . & $Y . \leqslant V$ & زمن العودة · ب ان لق & & \\
\hline$* 1.9 \vee 7$ & YI. $\leqslant Y$ & $17 V . \varepsilon$ & 19.0 & 1100.0 & قوة عضلات الظهر & \multirow{4}{*}{ 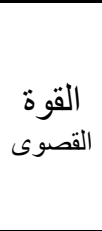 } & \\
\hline$*$ * . V & 7.01 & (T) & 9.19 & TVT & قوة عضلات الرجلين & & \\
\hline * & 0.9 & Tra & $\varepsilon .7 Y$ & $M \cdot . V$ & قوة القبضة بمنى & & \\
\hline$* Y . Y \wedge l$ & $\varepsilon .19$ & IrV.T & 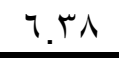 & 1 & قوة القبضة يسرى & & \\
\hline *ץ... A & 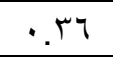 & $0 . \leqslant 7$ &.$\leqslant \varepsilon$ & $\varepsilon .94$ & \multicolumn{2}{|c|}{ القوة المميزة بالسرعة زمن (r) رميات خلفية بالشاخص } & \\
\hline *T.717 & .01 & $1 . .11$ & $\therefore V$ & 9.15 & \multicolumn{2}{|c|}{ الرشاقة زمن أداء الكوبرى (آمرات) } & \\
\hline$* 1 . \vee \mu q$ & ש.r. & $\varepsilon Y . V$ & $0 . \mu$ & TV.V & الافقية & \multirow{2}{*}{ 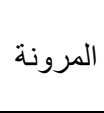 } & \\
\hline$*$ *. Av & Y..$\leq$ & $\varepsilon \vee .9$ & Y.VT & 01.7 & الر أسية & & \\
\hline$* \varepsilon .110$ & r. YT & ro.r & $r .7$ & ra.r & \multirow{2}{*}{\multicolumn{2}{|c|}{ 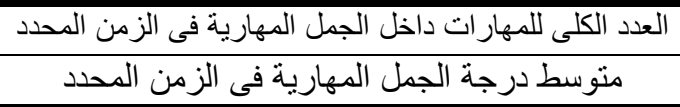 }} & \multirow{2}{*}{ المهارية } \\
\hline *IT.r &.$T^{\prime}$ & 7.9 & .01 & 9.0 & & & \\
\hline$* \eta . V \cdot \Lambda$ & 1.07 & 70 & 1.0 & 71 & \multicolumn{2}{|l|}{ معدل النبض فى الراحة } & \multirow{7}{*}{ 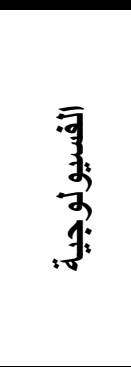 } \\
\hline * $\varepsilon .0 \mathrm{VV}$ &.$\vee \varepsilon$ & 7.9 &.$\wedge r$ & 0.1 & درجة الإنتاج (الخطو ات) & \multirow{3}{*}{ لكارلسنون } & \\
\hline$* \varepsilon . Y V V$ & $1.1 \varepsilon$ & $1 \cdot .1$ & 1.7 & A.V & درجة سر عة النبض & & \\
\hline$* \eta . \leqslant \vee 0$ & Y.TV & 70.7 & r.OV & $V T . Y$ & مستوى لياقة الجهاز الدوري و القلب & & \\
\hline$* 11.10$ &. .11 & $r . \varepsilon q$ & .17 & $\varepsilon . Y \varepsilon$ & \multicolumn{2}{|c|}{ كفاعة الجهاز التنفسى السعة الحيوية FVC } & \\
\hline$* 0 . \vee \vee 9$ & $Y 1.71$ & $\sum 17.0$ & TO.YI & $\varepsilon 9 r$ & \multicolumn{2}{|c|}{ الكفاءة اللاهو ائية مث على الاراجة الأرجومنرية } & \\
\hline$* 11.11$ & $\because 9$ & $r . \varepsilon r$ & .19 & 5.19 & \multicolumn{2}{|c|}{ الحد الأقصى لاستهلاك الاكسجين Vo2 max } & \\
\hline
\end{tabular}

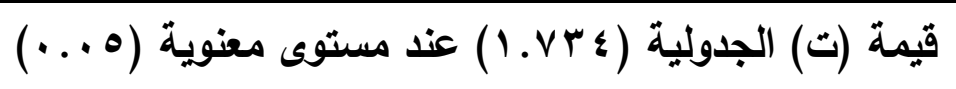

يتضح من جدول (9) وجود فروق دالة احصائية بين القياسين البعديين للمجموعتين التجريبية والضابطة لصالح المجموعة التجريبية في المتغيرات البدنية والمهارية والفسيولوجية قيد

$$
\text { البحث حيث ان قيمة اختبار (ت) المحسوبة أعلي من قيمة (ت) الجدولية. }
$$




\section{جدول (·)}

قيمة تأثير البرنامج "إيتا ؟" ونسبة التحسن بين القياس (القبلي/البعدى) للمجموعة التجريبية

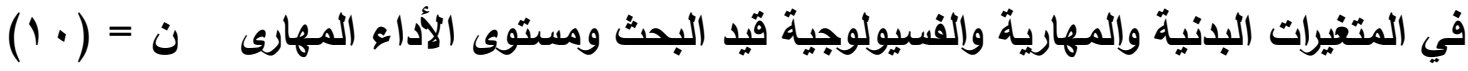

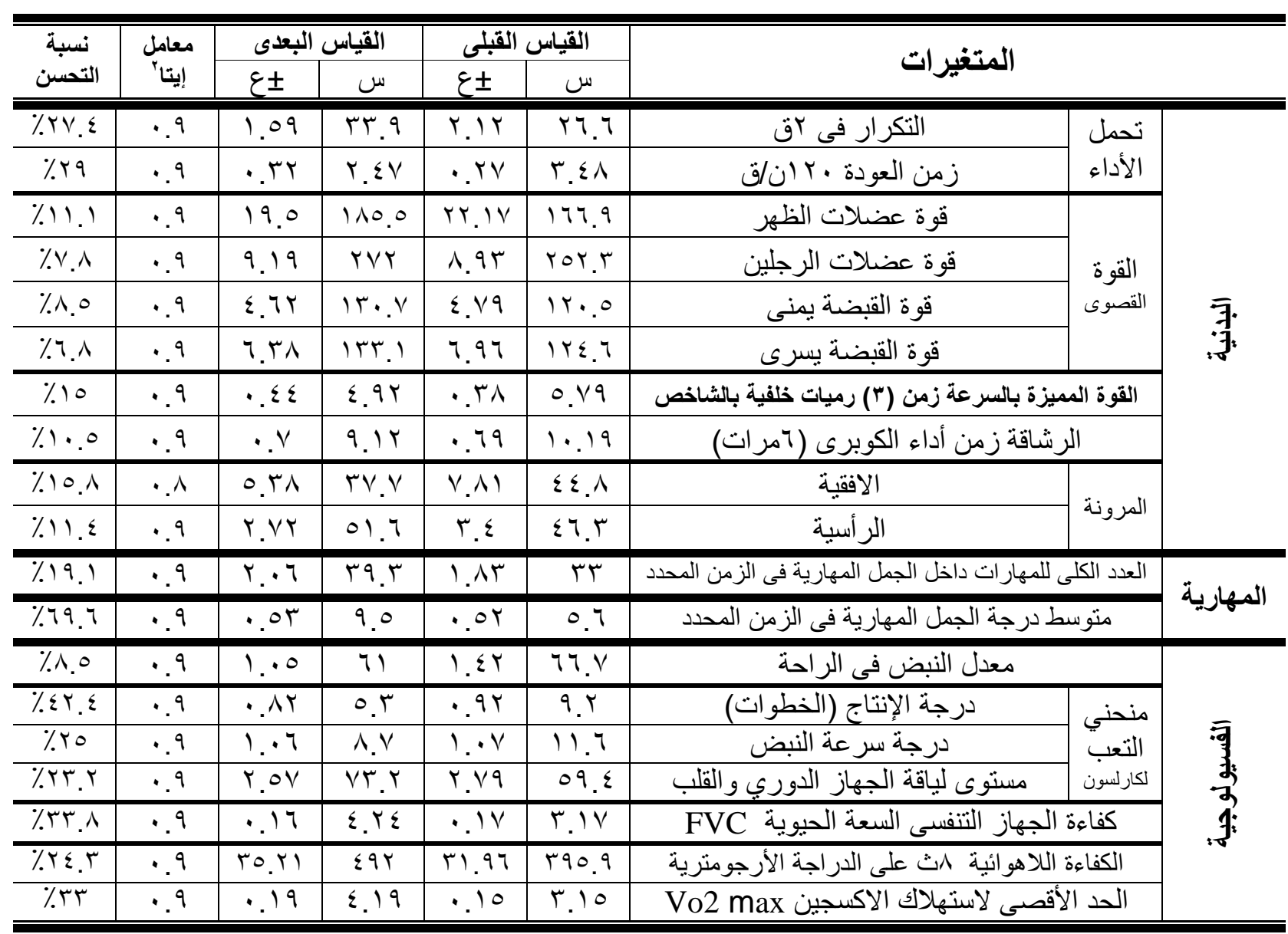

تثتير نتائج جدول (• (1) إلى أن قيمة ( إيتا؟) لجميع المتغيرات أعلى من (0. • ) مما يدل

على قوة تأثير البرنامج المقترح على المتغيرات البدنية والمهارية والفسيولوجية قيد البحث للمجموعة التجريبية و نسبة التحسن تراوحت بين (1. ؟٪، 7.9 ٪\%) بين القياس (القبلي/البعدى) للمجموعـة التجريبية في المتغيرات البدنية والمهارية والفسيولوجية قبد البحث فى اتجاه القياس البعدى. التقدير لمعامل ايتاب • • (من صفر إلى أقل من r. = = تأثير ضعيف)

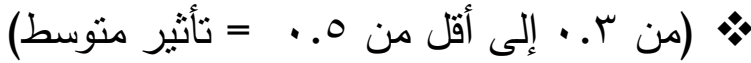
• (من 0. • إلى واحد صحيح = تأثثر قوي) 


\section{جلول (11) - (11)}

نسبة التحسن بين القياس (القبلي/البعدى) للمجموعة الضابطة

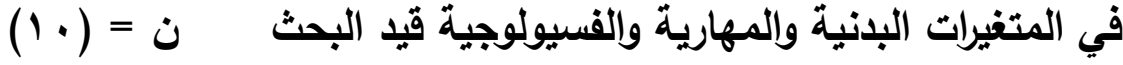

\begin{tabular}{|c|c|c|c|c|c|c|c|}
\hline \multirow{2}{*}{ التحسبة } & \multicolumn{2}{|c|}{ القياس البعدى } & \multicolumn{2}{|c|}{ القياس القبلى } & \multirow{2}{*}{\multicolumn{3}{|c|}{ المتغيرات }} \\
\hline & $\varepsilon^{ \pm}$ & س & $\varepsilon^{ \pm}$ & س & & & \\
\hline$\% 1 \cdot .9$ & 1.90 & rq.r & r.V & r7. & التكر ار فى بق & \multirow{2}{*}{ 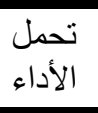 } & \multirow{10}{*}{ 牙: } \\
\hline$\% 9 . \vee$ & $\cdot r v$ & דצr. &.$\varepsilon \varepsilon$ & r.Vt & زمن العودة · بان/ق & & \\
\hline$\% .1$ & YI. $\leqslant Y$ & $17 V .5$ & TI.ro & 101.4 & قوة عضلات الظهر & \multirow{4}{*}{ القصوة القوة } & \\
\hline$\% .9$ & 7.01 & r4l & $7 . \leqslant 0$ & rol.r & قوة عضلات الرجلين & & \\
\hline$\%$ \%.! & 0.9 & Tr & $0 . V V$ & $119 . r$ & قوة القبضة يمنى & & \\
\hline$\%$ r.v & $\varepsilon .19$ & ITV.T & $\varepsilon . \vee 7$ & MT & قوة القبضة بسرى & & \\
\hline$\% \vee \wedge$ & דוr & $0 . \leqslant 7$ & דוח. & $0.9 r$ & \multicolumn{2}{|c|}{ القوة المميزة بالسر عة زمن (r) رميات خلفية } & \\
\hline 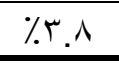 & .01 & $1 \cdot .11$ & $.0 Y$ & $1 \cdot .01$ & \multicolumn{2}{|c|}{ الرشاقة زمن أداء الكوبرى (آمرات) } & \\
\hline$\% 7 . \wedge$ & R.M & $\varepsilon r . V$ & V.Or & $\varepsilon 0 . \wedge$ & الافقية & \multirow{2}{*}{ 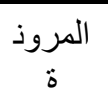 } & \\
\hline$\% 7 . \varepsilon$ & Y..$\varepsilon$ & $\varepsilon \vee . q$ & r.Ar & $\leqslant 0$ & 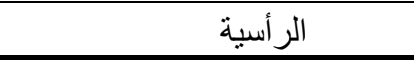 & & \\
\hline$\% 9.7$ & Y.YT & r. & $r .9$ & & \multicolumn{2}{|c|}{ العدد الكلى للمهار ات داخل الجمل المهارية فى الزمن } & \multirow[t]{2}{*}{ 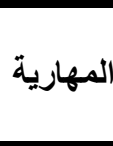 } \\
\hline$\% Y \vee . \wedge$ & . M & 7.9 & $.0 Y$ & $0 . \varepsilon$ & \multicolumn{2}{|c|}{ متوسط درجة الجمل المهارية في الزمن المحدد } & \\
\hline$\%$ \% & 1.07 & 70 & $1 . T \varepsilon$ & TV.r & \multicolumn{2}{|c|}{ معدل النبض في الر احة } & \multirow{7}{*}{ 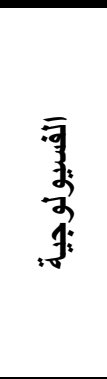 } \\
\hline \%Tr.r & $\cdot V \varepsilon$ & 7.9 & $\cdot \wedge Y$ & 9 & درجة الإنتاج (الخطو ات) & \multirow{3}{*}{ لتحني } & \\
\hline$\%$ \%. 9 & $1.1 \varepsilon$ & $1 \cdot .1$ & $1.1 \mathrm{~V}$ & IY. & درجة سر عة النبض & & \\
\hline$\%$ \%.V & T.TV & 70.7 & r.79 & $O \Lambda . Y$ & ى لياقة الجهاز الدوري و القلب & & \\
\hline$\% 11.9$ &. $.1 T$ & $r . \leqslant 9$ & .11 & r.IT & \multicolumn{2}{|c|}{ كفاءة الجهاز التنفسى السعة الحيوية FVC } & \\
\hline$\% 7.9$ & YI.71 & $\varepsilon 17.0$ & TY. EV & rᄉq. & \multirow{2}{*}{\multicolumn{2}{|c|}{ 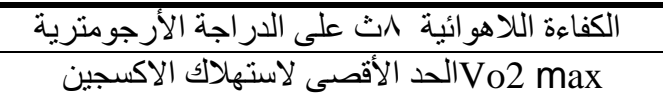 }} & \\
\hline$\% 1 \cdot . \mathrm{V}$ & $\because 9$ & $r . \Sigma T$ & $\because 99$ & $r .9$ & & & \\
\hline
\end{tabular}

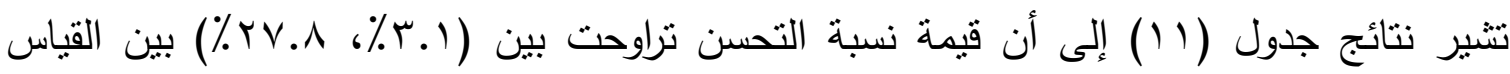
(القبلي/البعدى) للمجموعة الضابطة في المتغيرات البدنية والمهارية والفسيولوجية قبد البحث فى

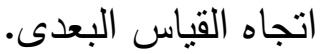
ثانيا مناقثة النتائج في ضوء العرض السابق للنتائج التي توصل إليها الباحث وفي إطار أهداف وفروض البحث واسترشاداً بنتائج الدراسات السابقة وما ورد بالمراجع العلمية يبدأ الباحث بمناقثة نلاك النتائج فيما 
يتضح من جدول (V) وجود فروق دالة إحصائيا بين القياس (القبلي/البعدى) للمجموعة التجريبية في الاختبارات قيد البحث حيث تراوحت قيمة (ت) المحسوبة لاختبارات تحمل الأداء (التكرار فى كق،

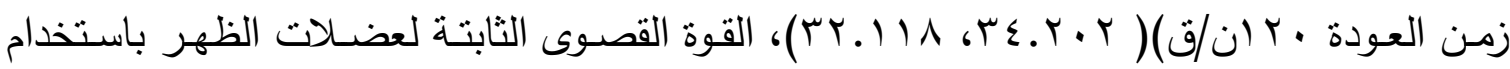

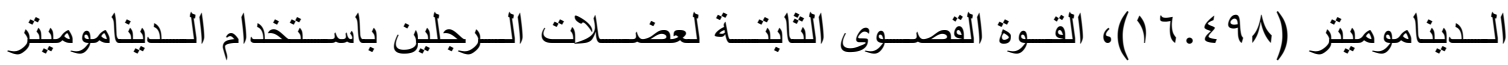

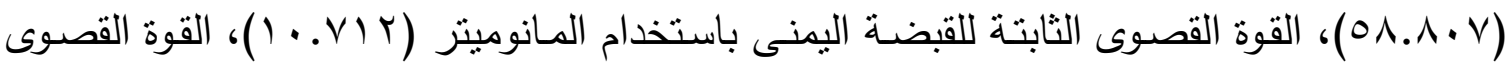

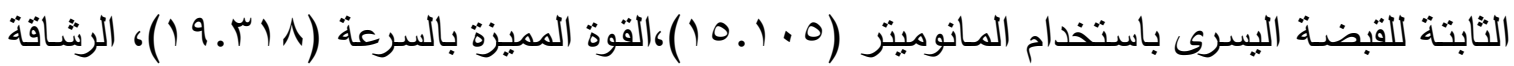

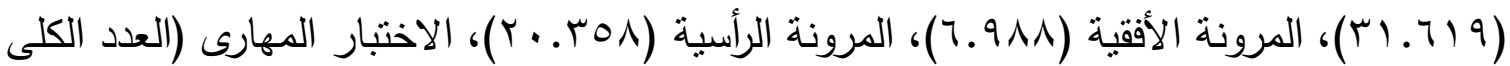
للمهارات داخل الجمل المهارية فى الزمن المحدد، متوسط درجة الجمل المهارية فى الزمن المحدد)( V Y.01V

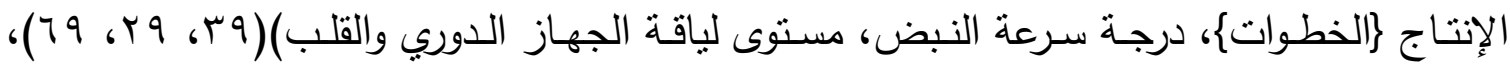

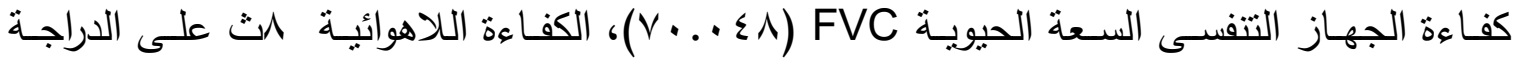

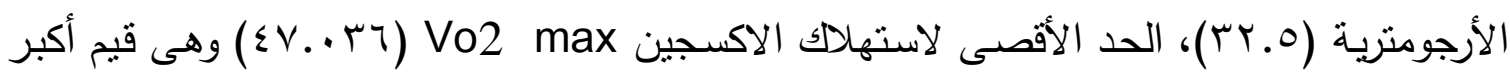
مـن قيمـة "ت" الجدوليـة والتي كانـت (سبهـ ( ) عند درجـة حربـة (9) ممـا يـدل على أن البرنـامج التذريبى المقترح باستخدام أسلوب التدريب المتقطع عالى الكثافة (Hiit) والذى احتوى على التدريبات البدنيـة العامـة والخاصـة والمهاريـة الموضوعة من قبل الباحث والتى راعى فيها العضـلات العاملـة والمسارات الحركية للأداء المهارى قد أثرت على المتغيرات البدنية والمهارية والفسيولوجية قبد البحث.

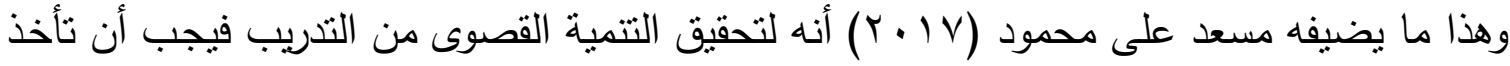
التمرينات شكل وطبيعة الأداء المهارى لنوع النشاط الممارس من حيث زمن الأداء، وطبيعة الأداء ، وتعاقـب فتـرات العــل والراحـة، والعضــلات العاملـة، والمســارات الحركيـة، والعنصـر المـراد (ङ): تتميته.

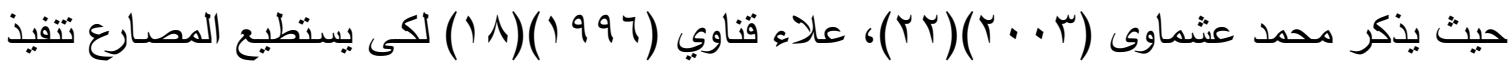
المهارات بفاعليـة فـى المباريـات فـإن ذلك يتطلب اعدادا خاصـا يتضـمن الجانب البدنى مرتبطسا بالجانب المهارى. 
فيجب الاهتمـام بأسلوب التدريب المتقطع عالى الكثافة (Hiit) والذى يساعد علي تتمبـة متطلبات الأداء والمنافسـة مـن حيـث تعاقب فترات العــل والراحـة، الأداء بالثــدة القصـوى والراحـة القصـيرة النشـة ممـا يسـاعد على تتميـة القدرات البدنيـة والمهاريـة والفسـيولوجية وهو مـا أدى إلى التحسن الواضتح لدى أفراد عنة البحث.

وتتفق نتائج هذه الدراسـة مـع مـا أشـار إليه محمد رضـا الروبـ (0 . . ب) أنه يجب الربط بين زمن الأداء، وشـكل الأداء والطاقـة المطلوبـة لإنجـازه، والقـوة والسـرعة التـى يـتم بهـا الأداء، واسـتخدام العضـات بالقدرة والتوقيت المناسـب، ودراسـة المتطلبـات المتعـدة البدنبـة والمهاريـة والفسـيولوجية لفاعلية الحركة.(؟ ب: (ب0)

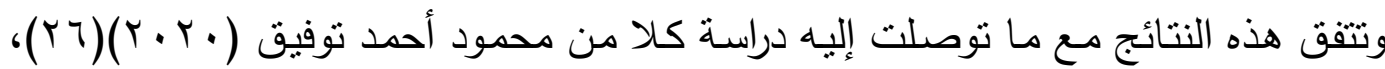

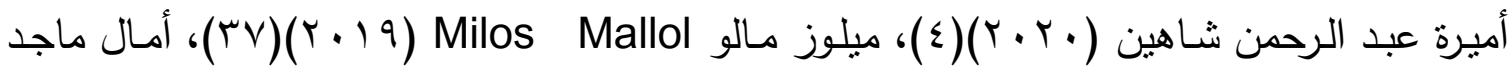

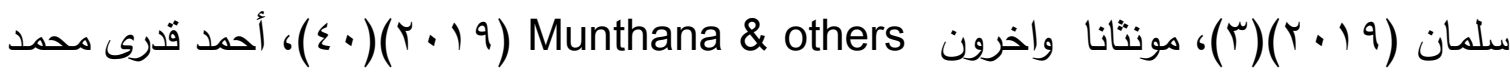

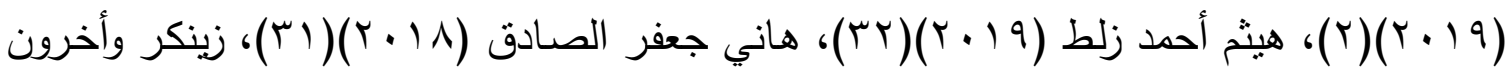
(Y) Zaenker P

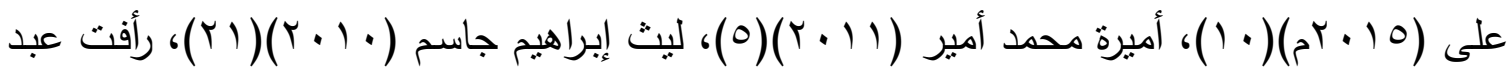

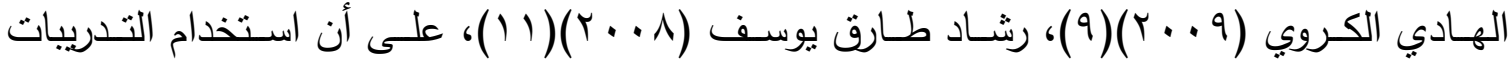
بأسلوب التدريب المتقطع عالى الكثافة (Hiit) لها تأثير إيجابى على تحسين الحالة البدنية والمهارية والفسيولوجية. كما يتضح من جدول (· () أن قيمة معامل "إيتاب" قوة تأثثر البرنامج كانت أكبر من (0. •) مما يدل ذلك على أن البرنامج التدريبى المقترح باستخدام أسلوب التدريب المتقطع عالى الكثافة (Hiit) والـذى كـان لـه قـوة تـأثنير كبيـرة وكـان ذا فاعليـة على تتميـة وتطـوير القـدرات البدنيـة والمهاريـة والفسيولوجية قيد البحث والذى راعى الباحث عند وضعه الأسس العلمية والذى يحتوى على تدريبات تتثابه فيها العمل العضلى مع منطلبات الأداء المهارى وفى نفس المسار العضلى والحركى ، مما كان له الأثر الكبير على تلك المتغيرات. 
وذللك يتفق مع ما أشنار أليه إيهاب البديوى (ع . . Y)(Y) إلى أن أساليب ووسائل التدريب المختلفة ما هى إلى تدريبات تطبيقيـة موجهه لتحقيق هدف العملية التدربيية، فيجب على المدرب معرفة هذه الوسائل والأساليب المختلفة والحديث منها واختيار ما هو مناسب وملائم لتحقيق أفضل مستوى أداء

حيث أن رياضة المصارعة من الرياضات التي يقع فيها اللاعب تحت حمل عالي في المباراة حيث تكون شدة الأداء عالية ويصاحب ذلك مجهود كبير على أجهزة الجسم واستمرار هذا المجهود خلال زمن المباراة يؤدى إلى تعرض اللاعب للتعب والإجهاد وعدم القدرة على مواصلة الأداء بنفس قوة بداية المباراة ، فأسلوب التدربب المتقطع عالى الكثافة (Hiit) يهتم بتلك المتطلبات خلال الأداء ويدعم هذه النتائج نسبة التحسن حيث نشير نتائج جدول (• () إلى نسبة التحسن بين القياسبين (القبلي/البعدى) للمجموعة التجريبية في المتغيرات قيد البحث لصالح القياس البعدى حيث تراوحت

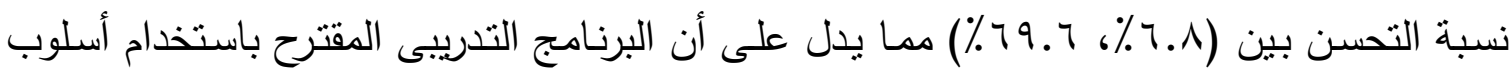
التدريب المتقطع عالى الكثافة (Hiit) والذى كان لـه قوة تأثنير كبيرة وكان ذا فاعليـة على تتميـة وتطوير القدرات البدنية والمهارية والفسيولوجية قيد البحث والذى راعى الباحث عند وضعه الأسس العلميـة والذى يحتوى على تدريبات تنتـابه فيها العمل العضلى مـع متطلبات الأداء المهارى وفى نفس المسار العضلى والحركى ، مما كان له الأثز الكبير على تلك المتغيرات. وأن استخدام الاختلاف عن المـألوف في طريقة التدريب قد أضـاف مبدأ التتوع والتغيير كمبدأ من مبادئ وأساسيات التدريب الرياضسى فسوف يزيل الرتابة والملل ويزيد من اندفاع اللاعبين على بذل الجهد في أداء وحداتهم التدريبيـة لتحدى قدراتهم أنتاء البرنامج التدريبى وهذا يؤدى إلى الإستفادة

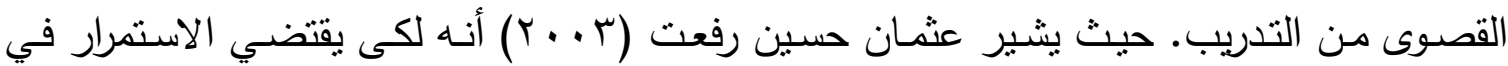
الصراع بكفاءة والمقدرة علي تتفيذ المهارات الهجومية مع الاحتفاظ بكفاءة وظيفية مرتفعة حتى نهاية المباراة، الأمر الذي يجعل اختيار طريقة التذريب المناسبة إحدى أهم الخطوات للوصول إلى أفضل

$$
\text { (1) (1) (1) (1) (1) }
$$

ويضيف كل من محمد حسن علاوي وأبو العلا عبد الفتاح ( . . . ب) أن المدرب الناجح هو الذي يخطط برنامجه التدريبي بحيث ينمي هذا البرنامج الخصائص التي يتطلبها نوع النشاط التخصصي 
للاعب ويشمل ذلك تدريب اللاعب باستخدام التدريبات التي تعمل علي تتميـة نظـام الطاقـة الذي يعتمد عليـة اللاعب في تخصصـه الرياضـي كمـا يجب أن تسـتخدم نفس الحركات الخاصـة بهذا النشـاط حتى يـتم التركيز علي تدريب المجموعـات العضـلية العاملـة والمشـتركة في أداء النشـاط الرياضي التخصصي تبعا لطبيعة عملها .(Tr: (YV) ويتضـح من جدول (^) وجود فروق دالة إحصائيا بين القياس (القبلي/البعدى) للمجموعة الضـابطة في في الاختبارات قيد البحث حيث تراوحت قيمة (ت) المحسوبة لاختبارات تحمل الأداء (التكـرار

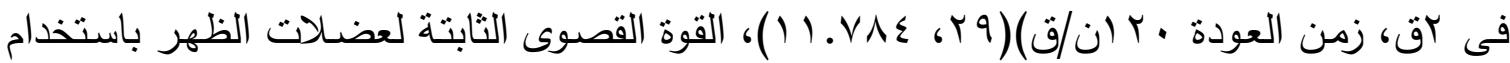

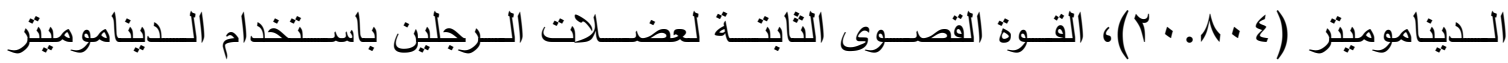

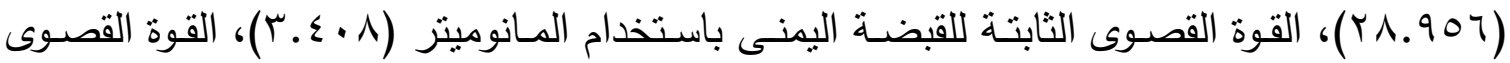

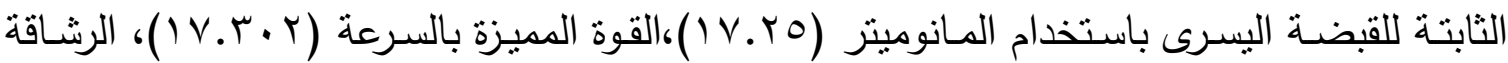

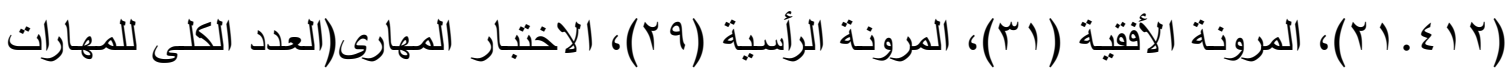
داخل الجمل المهارية فى الزمن المحدد، متوسط درجة الجمل المهارية فى الزمن المحدد)(اس، 9)،

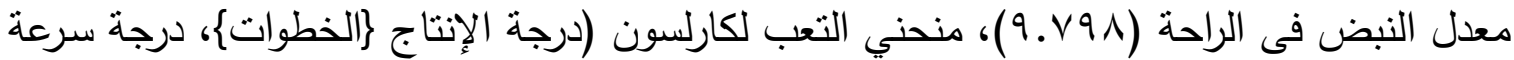

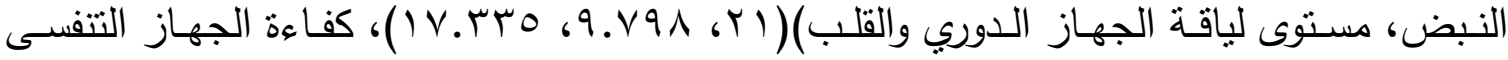

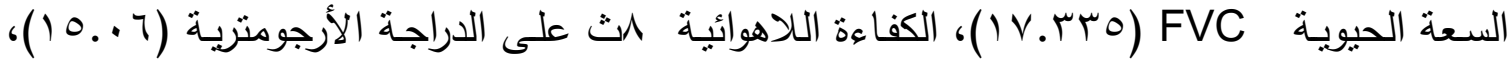

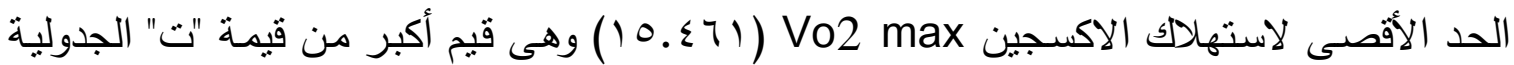
والتي كانت (سr^ـ ()) عند درجة حرية (9) مما يدل على أن البرنامج التدريبى التقليدى قد أثز على هذه المتغيرات قيد البحث نتيجة الاستمرار فى التدريب. وتتير نتائج جدول (1 (1) إلى نسبة التحسن بين القياسبين (القبلي/البعدى) للمجموعة الضابطة في

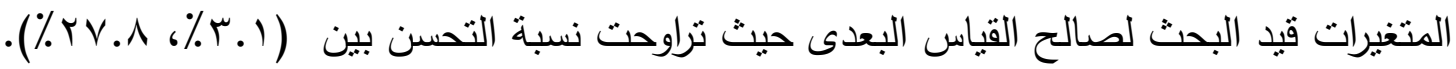
ويعزو الباحث هذه الفروق وهذا التحسن وهذا التقدم إلى أن البرنامج التدريبى التقليدى قد أدى إلى التحسن فى المتغيرات قيد البحث للمجموعة الضابطة وذلك لانتظام اللاعبين والتزامهم فى التدريب وتكرار اداء التدربيات والذى أدى بدوره إلى الارتقاء بـالمتغيرات قيد البحث وانتقال أثر 
التدريب حيث يذكر عادل عبد البصير (999 (19) أن عملية التكيف في التدريب لا يمكن أن تستمر أو تتطور إلا عن طريق التدريب المستمر المتواصل.(r I I ( ويضيف . James ,P,M, (799 ( ) حيث يثير إلى أن التدريب المنتظم يساعد الأعضاء الداخلية على التكيف مع أى عمل جديد مما يؤدى إلى ارتفاع مقدرة اللاعب الوظيفية.(بس: م0) ويتضـح من الجدول (9) إلى وجود فروق دالة إحصائيا بين المجموعتين (التجربيية/الضـابطة) في القيـاس البعـدى في الاختبـارات قيـد البحـث لصـالح المجموعـة التجريبيـة حيث كانـت قيمـة (ت) المحسوبة أكبر من قيمـة (ت) الجدولية عند مستوى معنويـة (0 . . ) والتي كانت (ع سV. () عند درجة حرية (1 (1) حيث تراوحت قيمة (ت) المحسوبة لاختبارات تحمل الأداء (التكرار فى بق، زمن

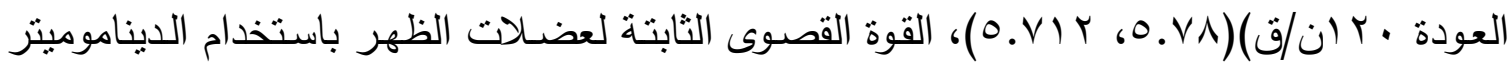

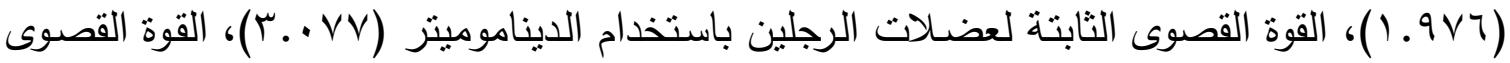
الثابتة للقبضة اليمنى باستخدام المانومينز (q وهـr)، القوة القصوى الثابتة للقبضة اليسرى باستخدام

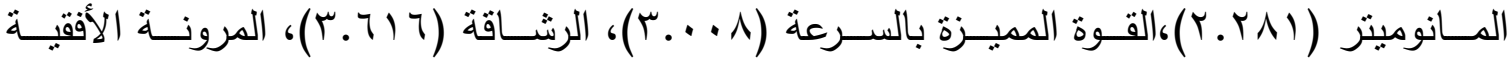

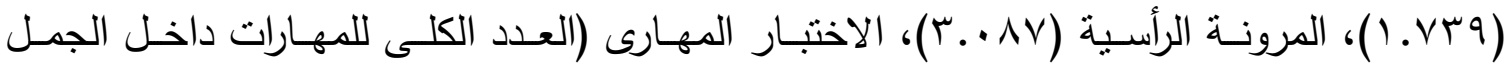

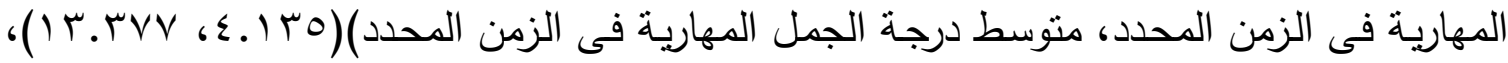

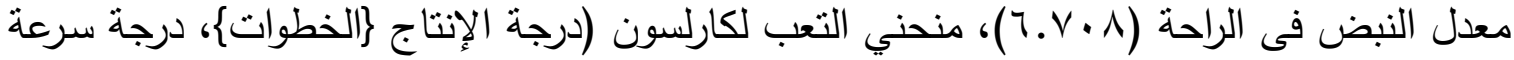

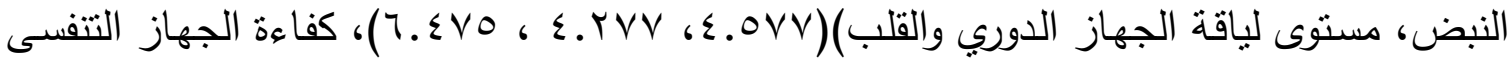

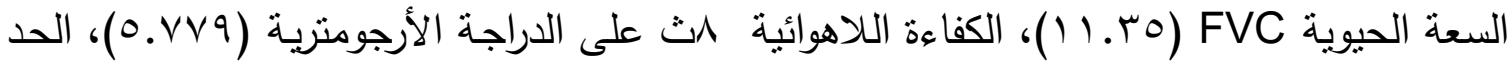

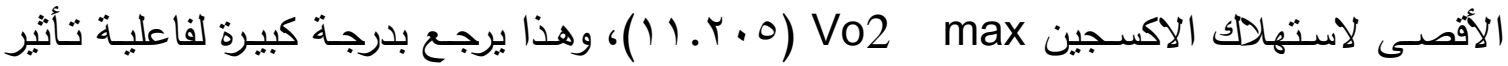
البرنـامج التدريبى المقترح باستخدام التدريبات الموضـوعة بأسـوب التدريب المتقطع عـالى الكثافـة من قبل الباحث كما نؤكد هذه النتائج أيضا بصورة غير مباشرة على صحة وتتكيل الأحمال (Hiit) التدريبيـة داخـل البرنـامج التـدريبى المسـتخدم وفقـا لأسـلوب علمى بالإضــافة إلى سـلامة اختيـار التدريبات المستخدمة والاهتمام بصحة وسرعة أدائها حيث يضيف مسعد على محمود ( . . r) أن التدريب يتعلق فى المقام الأول بتتمية القدرات الخاصـة بالأداء المهارى للمنافسات، ويهدف برنامج التدريب إلى تحسين القدرات الوظيفية للجسم بالإضافة لتنمية الأداء الفنى والخططى ويعطى برنامج 
التدريب اعتبـارا متشـاويا لكل مـن القدرات البدنيـة والمهاريـة والوظيفيـة، أى يهتم بالإعداد الثـامل والمتتوع الذى يهتم بالتفاصيل الأخرى للبرنامج كالراحة واستعادة الثفاء.(^r : وبr) ويدعم هذه النتائج نسبة التحسن حيث تشير نتائج جدول (• ())، (1 (1) إلى الفرق بين نسبة التحسن التى حدثت فى المستوى بين البرنامج المقترح والبرنامج التقليدى. ويرى الباحث أن هذه الفروق ونسب التحسن لدى المجموعة التجريبية يرجع إلى البرنامج التدريبى المقترح والذى استخدم أسلوب التدريب المتقطع عالى الكثافة (Hiit) في تطبيق تدريبات البرنـامج البدنيـة والمهاريـة والــى طبـق على المجموعـة التجريبيـة ونظـرا لأن الفـرق الوحيـد بـين المجموعتين هو أسلوب التدريب المتقطع عالى الكثافة (Hiit) المستخدم فإن الباحث يعزو تفوق المجموعة التجريبية على المجموعة الضابطة فى المتغيرات البدنية والمهارية والفسيولوجية قيد البحث إلى هذا الأسلوب في التدريب الذى تم تطبيقه على المجموعة التجريبية. كما أن التدربيات المستخدمة بأسلوب التدريب المتقطع عالى الكثافة (Hiit) والتى ركزت على الأداء الفردى واتسمت بصفة التتوع والتتـويق والدافعيـة نحو الأداء قد أثرت على الأداء البدنى والمهارى وأدى ذلك إلى التأثنر الإيجابى على النواحى الفسيولوجية لاى المجموعة التجريبية.

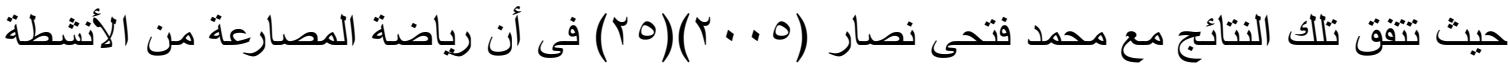
التي تتطلب مستوي عال مـن الكفاءة البدنية والفسيولوجية حتى يتمكن اللاعب مـن أداء واجباته المهارية والخططية المكلف بها طوال المباراة بكفاءة عالية. حيث يضيف أيهاب صبرى، نبيل الثوربجى (T . . r)(T) أن المصارعة من الرياضات التى تتطلب بذل مجهود بدنى شاق أثناء التدريب أوالمباريات وهذا يتطلب قدرات بدنية ووظيفية خاصة للاعبى المصارعة.

حيث يضيف بى فاسكونكلوز وأخرون B. Vasconcelos and others ( • • • (r) (r) على آثار التدريب الفاصل عـالي الكثافة في رياضـات النزال حيث أن رياضـات المنـازلات متقطعة بطبيعتها فيفضل استخدام التدربب المتقطع عالي الكثافة (HIIT) كأداة للحفاظ على اللياقة البدنية وتحسينها بين رياضـات فنـون الدفاع عن النفس، الجودو، التايكونـدو، الجيو جيتسـو، الملاكمـة، الكاراتيـه، المصارعة، الوشو كونج فو، فسوف تعمل على تحسن فى القدرات الهوائية، ومعدل ضربات القلب، 
والحد الأقصى لاستهالاك الأكسجين، القدرة اللاهوائية القصوى والمتوسطة، وتركيز حمض اللاكتك في الدم، ونسبة الدهون في الجسم، والتأثثر على كتلة الجسم ونسبة الدهون في الجسم. ويضيف عصام عبد الخالق (r . . r) إلى أن اتقان الأداء المهارى يعتمد على مدى تطوير متطلبات هذا الأداء من قدرات بدنية خاصـة وكثيرا مايقاس مستوى الأداء المهارى بمدى اكتساب الفرد لهذه

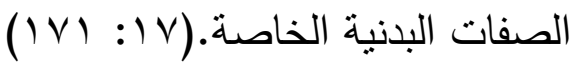

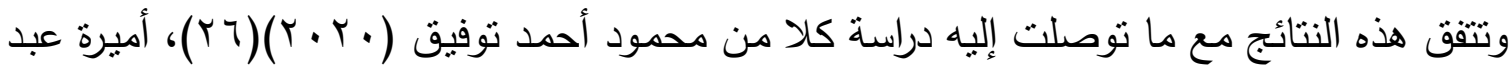

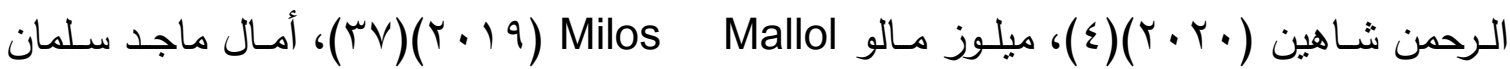

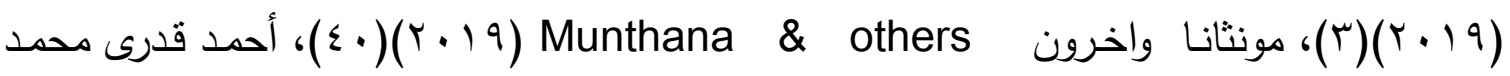

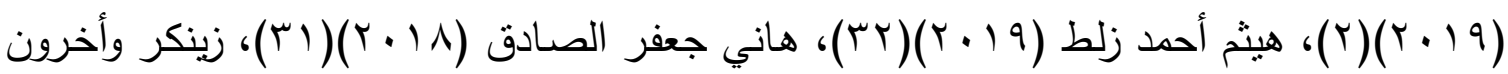
(Y) Zaenker P

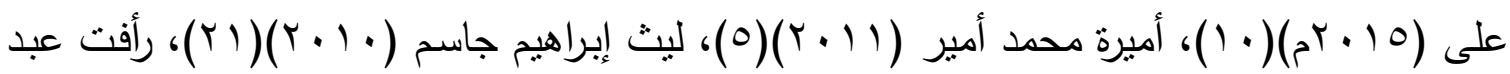

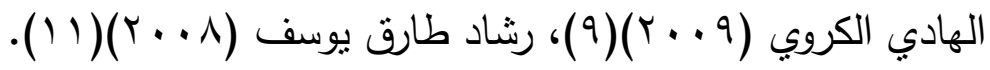

وهذا ما يتفق مع مبدأ الخصوصية فى التدريب وكذلك مراعاة الفروق الفردية لكل لاعب حيث يذكر

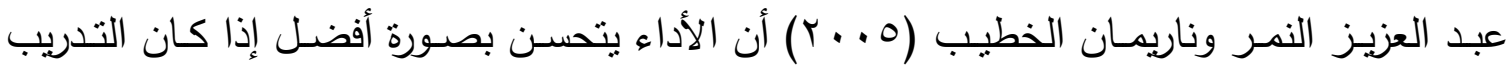
خاصا بنوع النشاط الممارس وأن يتضمن أهم العضلات العاملة فى هذا النشاط وأن تتم بنفس كيفية استخدامها فى المنافسة.( ( : ( ) ) ومما سبق نجد أن البرنامج التدريبى المقترح والمطبق على المجموعة التجريبية والذى والذى استخدم أسلوب التدريب المتقطع عالى الكثافة (Hiit) في تطبيق تدريبات البرنامج البدنية والمهارية كان له تأثيرا إيجابي على تتمية المتغيرات البدنية والمهارية والفسيولوجية وبذلك تحققت فروض البحث.

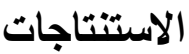
في ضوء أهداف وطبيعة هذه الدراسة وفي حدود عينة البحث والمنهج المستخدم، ومن واقع البيانات التي تجمعت لاى الباحث ونتائج التحليل الإحصائي توصل الباحث إلى الاستتاجات التالية ا- البرنـامج التدريبى المقترح باستخدام أسلوب التدريب المتقطع عالى الكثافة (Hiit) أثر إيجابيا على تتمية الحالة البدنية قيد البحث لدى المجموعة التجربيية. 
r- البرنامج التدريبى المقترح باستخدام أسلوب التدريب المتقطع عالى الكثافة (Hiit) أثر إيجابيا على تتمية الحالة المهارية قبد البحث لدى المجموعة التجريبية. r- البرنامج التدريبى المقترح باستخدام أسلوب التدريب المنقطع عالى الكثافة (Hiit) أثر إيجابيا على تتمية الحالة الفسيولوجية قبد البحث لاى المجموعة التجريبية. ؟- البرنامج التدريبى المقترح باستخدام أسلوب التدريب المتقطع عالى الكثافة (Hiit) أفضل من بن البرنـامج التقليدى على تطـوير الحالـة التدريبيـة البدنيـة والمهاريـة والفسـيولوجية لـدى المجموعـة التجريبية. التوصيات في حدود ما اشتملت علية الدراسة من إجراءات ، وما أسفرت عنه من نتائج ، يوصي الباحث بالأتي 1- الاهتمام بالتدريب بأسلوب التدريب المتقطع عالى الكثافة (Hiit) وفقا للمبادئ العلمية خلال برامج إعداد المصارعين نظرا لملائمنه لطبيعة أداء المنافسة. r- الاهتمـام بالتـدريب بأسلوب التدريب المتقطـع عـالى الكثافـة (Hiit) وفقـا للمبـادئ العلميـة لرياضات المنازلات والرياضات التى يتتاوب الأداء بها بين العمل والراحة.

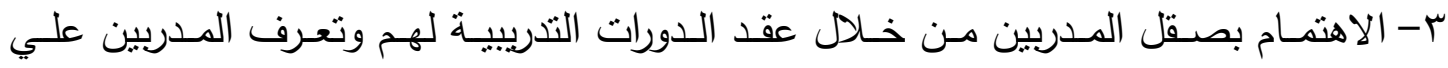
الأساليب التدريبية الحديثة.

ع- ضرورة تصميم برامج مشابهه للمراحل السنية الدختلفة. ه- ضرورة تصميم برامج مشابهه باستخدام أسلوب التثريب المنقطع عالى الكثافة (Hiit) ومعرفة تأثنيره على متغيرات واستجابات أخرى . צ- ضرورة التتويع فى استخدام الوسائل والأدوات والأجهزة عند نطبيق أسلوب التدريب المتقطع عالى الكثافة (Hiit). V- اجراء دراسات مقارنة بين طريقة التدريب المتقطع عالى الكثافة (Hiit) والطرق الأخرى. 


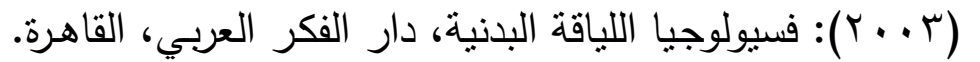

ا أبو العلا عبد الفتاح، أحمد نصر الدين

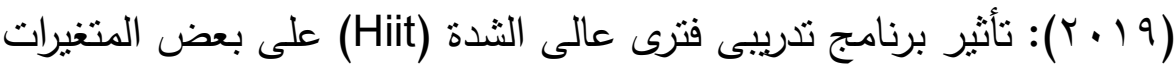

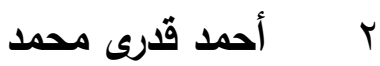
الصحية لاى السيدات ، المجلة العلمية للتربية البدنية وعلوم الرياضة، عVیى، كلية التربية الرياضية للبنين، جامعة حلوان.

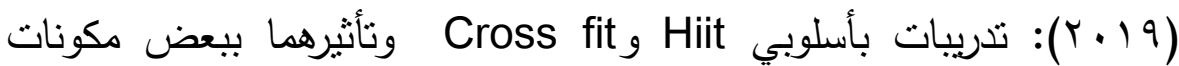
اللياقة البدنية- الصحية للنساء بأعمار (•r-هץ)، رسالة دكتوراه، كلية التربية البدنية وعلوم الرياضة للبنات، جامعة بغداد.

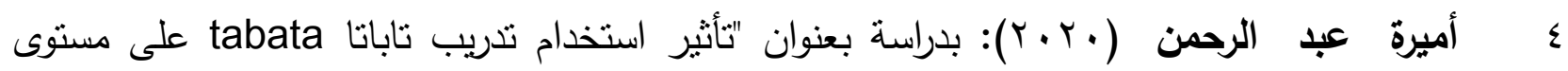
الكفاءة الفسيولوجية ومستوى الأداء المهارى فى التسس الأرضى، المجلة

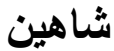
العلمية للتربية البدنية وعلوم الرياضة، عیى، كلية التربية الرياضية للبنين،

$$
\text { جامعة حلوان. }
$$

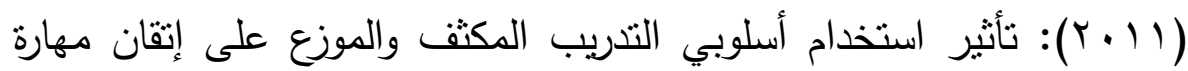
م أميرة محمد أمير الإرسال والرضا الحركي في الكرة الطائرة ، بحث علمي منشور، مجلة علوم

$$
\text { وفنون التربية الرياضية، أسيوط. }
$$

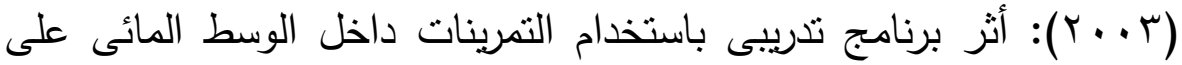
كفاءة الجهازين الدورى والتتفسى وفاعلية الأداء المهارى للمصارعين، المجلة الثوريجى

العلمية لعلوم التربية الرياضية، كلية التربية الرياضية، جامعة طنطا. V

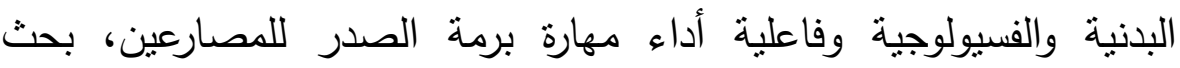
منشور، المجلة العلمية، المجلد الأول، كلية التربية الرياضية للبنات، جامعة

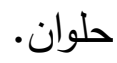

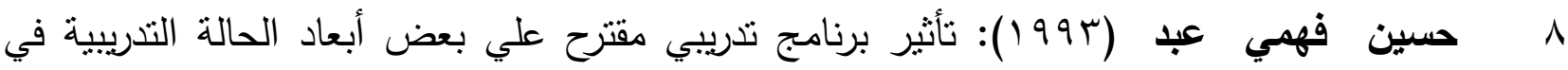


المصارعة، رسالة دكتوراه، كلية التربية الرياضية، جامعة المنيا ـ الظاهر

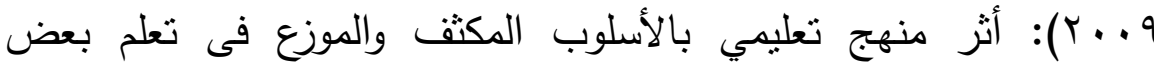
المهارات الأساسية بكرة القدم للاكور والإناث للفئة العمرية (V- (9) سنوات، الههادي

كلية علوم التربية الرياضية ، العدد الثالث ، المجلد الثاني، جامعة القادسية.

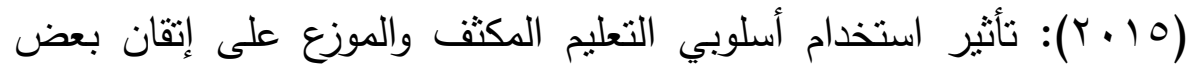

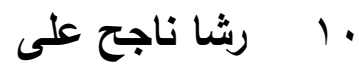
المهارات الحركية في مسابقات الميدان والمضمار، بحث علمي منشور، المؤتمر الدولى لعلوم الرياضة، كلية التربية الرياضية، جامعة أسيوط.

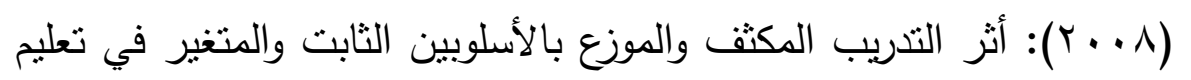
| بعض أنواع التهديف بكرة السلة لعدر (Y (1-乏 ) سنة، مجلة الرافدين لعلوم

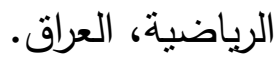

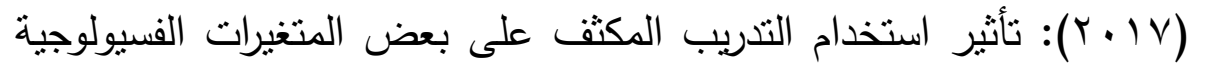
r إرة محمد الاثرم، والبدنية الخاصة بمباراة النقة الذهبية وفق تعديل قانون رياضة الجودو، ريهام محمد الأشرم المجلة العلمية للتربية البدنية وعلوم الرياضة، عاد، كلية التربية الرياضية

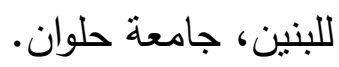

(999 (199): التدريب الرياضى والتكامل بين النظرية والتطبيق، مركز الكتاب rا للنشر ، القاهرة.

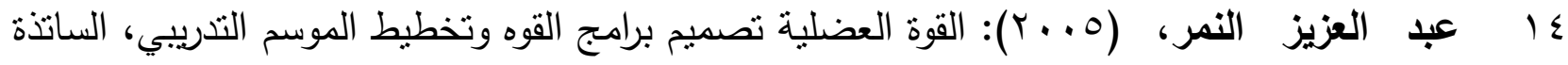

$$
\text { ناريمان الخطيب ل لكتاب الرياضى، الجيزة. }
$$

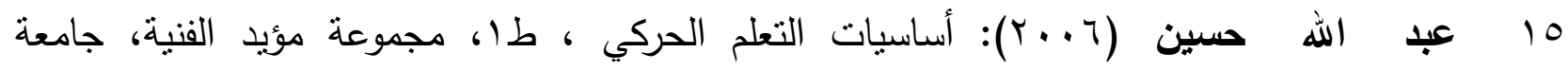
القادسبة. اللامي

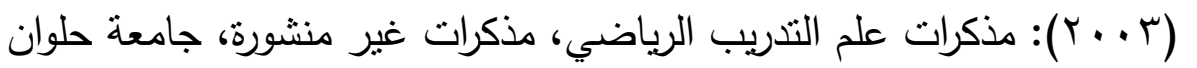
17

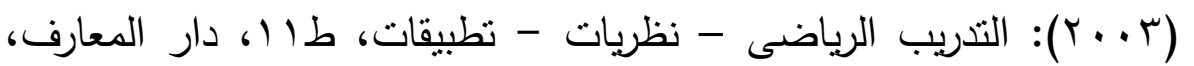
IV الأسكندرية.

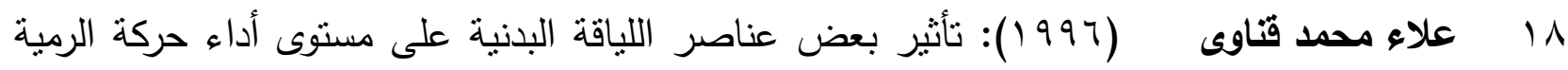


الخلفية في المصارعة، رسالة دكتوراه، كلية التربية الرياضية، جامعة الزقازيق.

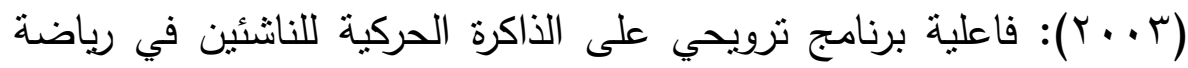
الكاراتيه، رسالة ماجستير، كلية التربية الرياضية، جامعة طنطا. 19 19 المغريل

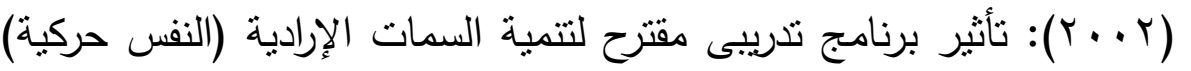
r بلى السعيد ريحان على فاعلية الأداء الفنى للمصارعين الكبار، المؤتمر العلمى الدولى، كلية التربية الرياضية للبنين، جامعة الإسكندرية.

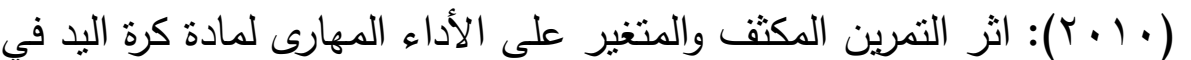
إبث إبراهيم جاسم التربية الرياضية، جامعة دالي.

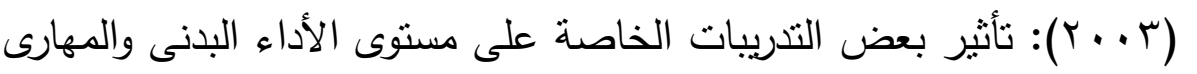
السيد

محمد لحركة مسك الوسط والرفع للتقوس للمصارعين، رسالة ماجستير، كلية التربية

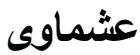
الرياضية، جامعة الزقازيق.

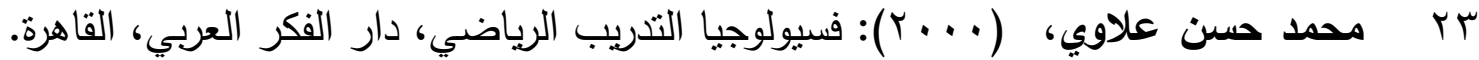
أبو العلا أحمد عبا

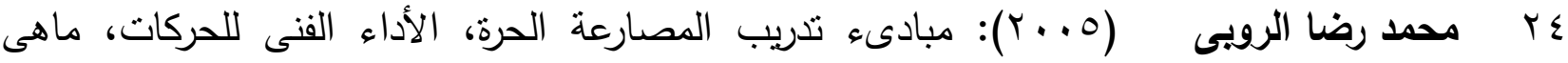
لخدمات الكمبيوتز ، الاسكندرية.

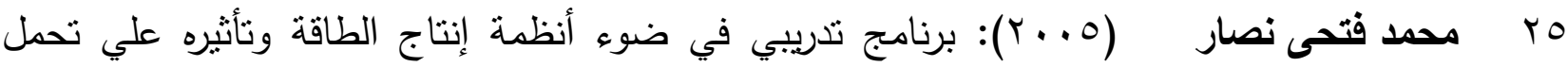
الأداء وفقاً لتعديلات قانون المصارعة، رسالة ماجستير غير منشورة، كلية التربية الرياضية، جامعة المنوفية.

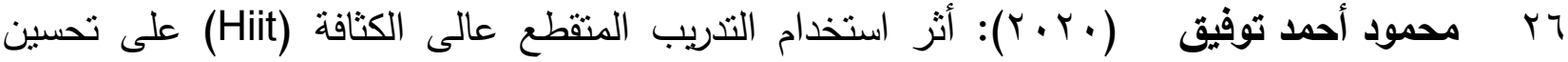
مستوى اللياقة البدنية وإنقاص الوزن للمصارعين ، المجلة العلمية لعلوم وفنون الرباضة، ع V ا، كلية التربية الرياضية للبنات، جامعة حلوان.

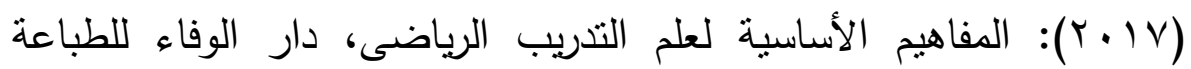
مسعد علي محمود TV والنشر ، الأسكندرية. 


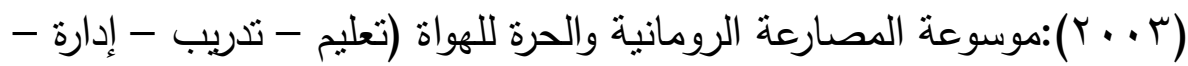

T^ تحكيم)، دار الكتب القومية، المنصورة.

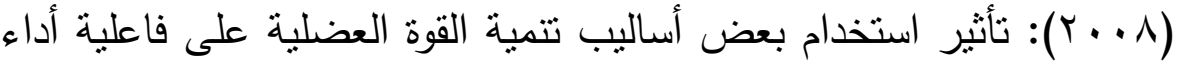

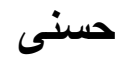

ن ن

مهارة رفعة الوسط العكسية للمصارعين، المؤتمر العلمى الدولى العانشر لعلوم

الشوريجى

التربية البدنية والرياضة، كلية التربية الرياضية للبنين، جامعة الأسكندرية.

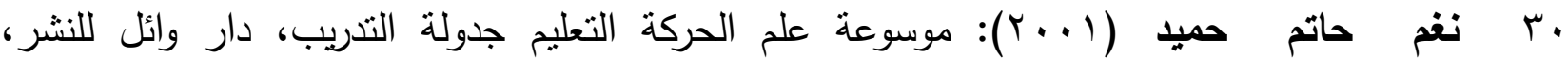
بغداد. الطافي

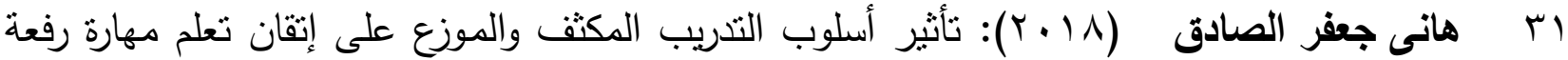
الوسط العكسية في المصارعة لاى طلاب كلية التربية الرياضية - جامعة سوهاج، مجلة علوم الرياضة- كلية التربية الرياضية- جامعة المنيا.

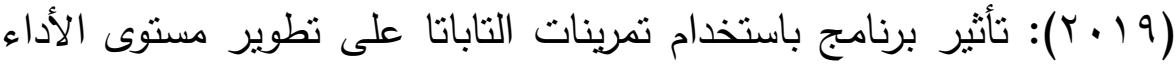
r ب ت هيثم أحمد زلط

الخططى للافاع والهجوم المضاد للمصارعين، المجلة العلمية للتربية البدنية وعلوم الرياضة، عَ1،، كلية التربية الرياضية للبنين، جامعة حوان.

33 B. Vasconcelos (2020): Effects of High-Intensity Interval Training in and others

34 Belal Morsy Witwit

35 Gina WIsker \& Sally Brown

36 James ,P,M,. Combat Sports: A Systematic Review with MetaAnalysis Breno, National Strength and Conditioning Association. Unauthorized reproduction of this article is prohibited (2015):training program FOR Development endurance performance and its effect on some physiological variables for wrestlers, International Journal of Sport Science \& Arts (IJSSA), Faculty of Physical Education for Girls in gezira (2008): Enabling Student Learning Systems Strategis, London, Kogan, Pase, 182,.

(1996): Soccer skills for in dividual getting and 
37 Milos Mallol, David J.

Bentley, Lynda Norton

38 Mohamed Fathi Nassar
39 Mosston, M. \& Ashworth, S.

40 Munthana Wadthaisong\& others

41 Schmidt. A. Richard and Tim. Othy, D. Lee

42 Zaenker P1,\& others team play, Engle wood cliffs, New York, Jersey. (2019): Comparison of Reduced-Volume HighIntensity Interval Training and High-Volume Training on Endurance Performance in Triathletes, International Journal of Sports Physiology and Performance.

(2017): The effect of a specific training program on improving the special endurance level and some physiological variables of wrestling players according to the amendments to international law 2016, International Journal of Sport Science \& Arts (IJSSA), Faculty of Physical Education for Girls in gezira.

(2006): Teaching Physical Education, 3rd ed., Merrill Publishing, U.S.A (2019): Effects of High-Intensity Interval Training in of maximal oxygen uptake responses cardiometabolic health, international Journal of health Science.

(2008) Motor control and learning third Edition, Human Kinetics.

(2017): High-intensity interval training combined with resistance training improves physiological capacities, strength and quality of life in multiple sclerosis patients, European Journal of Physical and Rehabilitation Medicine.

43 https://ar.wikipedia.org

44 https://arabianbodybuilding.com

45 https://copew.uobaghdad.edu.iq/?p=20557

46 https://leaqa.com/what-is-hiit-and-its-benefits-and-a-suggested-hiittable/

47 https://myfitnesscare.com/hiit/ 
48 http://www.alkhaleej.ae

49 https://www.egyfitness.com/hiit/

50 https://www.facebook.com/alfathgym/posts/504087819801686/

51 https://www.fitness-arabia.com

52 https://www.fitnessespresso.com/hiit

53 https://www.fitnessespresso.com/hiit-vs-tabata/

54 https://www.mayoclinic.org

55 https://www.tmareen.com 